\title{
Bi-functionalized aminoguanidine-PEGylated periodic mesoporous organosilica nanoparticles: a promising nanocarrier for delivery of Cas9-sgRNA ribonucleoproteine
}

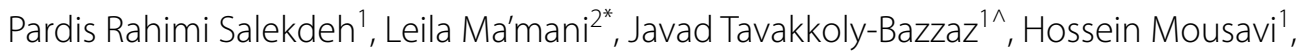
Mohammad Hossein Modarressi ${ }^{1}$ and Ghasem Hosseini Salekdeh ${ }^{3,4^{*}}$

\begin{abstract}
Background: There is a great interest in the efficient intracellular delivery of Cas9-sgRNA ribonucleoprotein complex (RNP) and its possible applications for in vivo CRISPR-based gene editing. In this study, a nanoporous mediated geneediting approach has been successfully performed using a bi-functionalized aminoguanidine-PEGylated periodic mesoporous organosilica (PMO) nanoparticles (RNP@AGu@PEG ${ }_{1500}-\mathrm{PMO}$ ) as a potent and biocompatible nanocarrier for RNP delivery.

Results: The bi-functionalized MSN-based nanomaterials have been fully characterized using electron microscopy (TEM and SEM), nitrogen adsorption measurements, thermogravimetric analysis (TGA), X-ray powder diffraction (XRD), Attenuated Total Reflectance-Fourier Transform Infrared Spectroscopy (ATR-FTIR), and dynamic light scattering (DLS). The results confirm that AGU@PEG 1500 -PMO can be applied for gene-editing with an efficiency of about $40 \%$ as measured by GFP gene knockdown of HT1080-GFP cells with no notable change in the morphology of the cells.

Conclusions: Due to the high stability and biocompatibility, simple synthesis, and cost-effectiveness, the developed bi-functionalized PMO-based nano-network introduces a tailored nanocarrier that has remarkable potential as a promising trajectory for biomedical and RNP delivery applications.

Keywords: Aminoguanidine Functionalized, Bi-functionalized Periodic Mesoporous Organosilica Nanoparticles, Cas9sgRNA Ribonucleoproteine, Delivery nano-system, Gene editing, PEGylated, RNP
\end{abstract}

\section{Background}

\footnotetext{
*Correspondence: leila.mamani@abrii.ac.ir; hosseini.salekdeh@mq.edu.au ${ }^{\wedge} T$ The authors would like to dedicate this paper to the memory of Prof. Javad Tavakkoly-Bazzaz, who died of cancer on September 26, 2020. He was a wonderful colleague who worked on various medical genetic sciences

${ }^{2}$ Department of Nanotechnology, Agricultural Biotechnology Research Institute of Iran (ABRII), Agricultural Research Education and Extension Organization (AREEO), Karaj, Iran

${ }^{3}$ Department of Systems and Synthetic Biology, Agricultural Biotechnology Research Institute of Iran (ABRII), Agricultural Research Education and Extension Organization (AREEO), Karaj, Iran

Full list of author information is available at the end of the article
}

The use of clustered regularly interspaced short palindromic repeats (CRISPR)/CRISPR-associated protein9 (CRISPR-Cas9) system associated protein9 (CRISPRCas9) has revolutionized gene-editing therapeutics [1, 2]. CRISPR-Cas9 based gene-editing tools have widespread applications in basic biomedical and biological researches, biotechnology-based product development, and gene therapy [3-7]. Over the last few years, this technology has been used for HIV-1/AIDS therapy $[8,9]$, cancer therapy $[10,11]$, gene expression regulation [12-14], and DNA/RNA imaging $[15,16]$. In order to effectively

c) The Author(s) 2021. This article is licensed under a Creative Commons Attribution 4.0 International License, which permits use, sharing, adaptation, distribution and reproduction in any medium or format, as long as you give appropriate credit to the original author(s) and the source, provide a link to the Creative Commons licence, and indicate if changes were made. The images or other third party material in this article are included in the article's Creative Commons licence, unless indicated otherwise in a credit line to the material. If material is not included in the article's Creative Commons licence and your intended use is not permitted by statutory regulation or exceeds the permitted use, you will need to obtain permission directly from the copyright holder. To view a copy of this licence, visit http://creativecommons.org/licenses/by/4.0/. The Creative Commons Public Domain Dedication waiver (http://creativecommons.org/publicdomain/zero/1.0/) applies to the data made available in this article, unless otherwise stated in a credit line to the data. 
utilize the CRISPR-Cas9-mediated genome editing technology for gene therapy, it is crucial to develop appropriate delivery systems. Generally, CRISPR-Cas9 system can be delivered via three different approaches including DNA plasmid that encompasses Cas9 and guide RNA (gRNA) [17], mRNA expressing Cas9 and a separate gRNA [18], and Cas9/single-guide RNA (sgRNA) complex (Cas9-sgRNA) as ribonucleoprotein complex (RNP) [19]. The plasmid-encoded Cas9 delivery has disadvantages such as the possibility of direct integration into genomic DNA, long time expression of Cas9 evoked immune responses, and off-target effects [20].

In contrast, the delivery of RNP has several advantages including fast action, high gene-editing efficiency, reduced off-target effects, immune responses, and no necessity of codon optimization, and promoter selection [21]. Several physical approaches including microinjection and electroporation have been reported for RNP delivery, while some undesirable properties such as the complicated behaviours and the requirement for direct access to the target tissue made their translation from in vitro studies to in vivo too difficult [22-24]. Viral vectors as highly efficient vehicles are used for the delivery of CRISPR-Cas9. However, viral vectors tend to cause undesirable immune responses and they are not usable for protein delivery $[25,26]$. Therefore, it is vital to provide an efficient non-viral RNP delivery system with high stability and efficient gene-editing.

To address these challenges, the utilization of the nanocarriers seems to be a promising strategy for smart and targeted delivery of RNP [27]. In this context, several strategies including nuclear localization signals or sequences (NLSs) [28], cell-penetrating peptides (CPPs) [29], cationic lipids [30, 31], graphene oxide (GO) nanosheets [32], gold nanoparticles [33], DNA nanoclews (NCs) [34], and zeolitic imidazole frameworks (ZIFs) [35] have been reported for RNP delivery. But these strategies suffer from some disadvantages such as low efficacy, toxicity, poor chemical stability, and poor controlled degradation.

Due to various features including size, morphology, availability of the functionalized groups, surface charge, and higher delivery efficiency compared to the other analogues, there is a growing interest in nanoporous materials in developing nanocarriers for delivery of biological molecules [36-42]. Recently, mesoporous silica nanoparticles (MSN) have been recognized as promising nanocarriers for drug and gene delivery due to their unique ordered porous nanostructured, large pore volume, good stability, high surface area, acceptable biocompatibility, ease of surface functionalization, and loading/release efficacy [43-45]. MSNs-based nanostructures offer unique features for attaining appropriate nanocarriers for various exploitation that cannot be easily met by the other nanostructures [46-48]. Although these nanomaterials have had a worthy improvement in RNP delivery [27-35], there is still great potential for the nanoporousbased materials to offer improved novel nanovehicles for RNP delivery.

As a prominent representative of the organic-inorganic hybrid nanoporous materials, periodic mesoporous organosilicas (PMOs) offer well-distributed organic bridged functionalities over the whole mesostructured framework. PMOs are constructed through self-assembling or hydrolysis and condensation of the bridged silsesquioxanes $(\mathrm{RO})_{3}-\mathrm{Si}-\mathrm{R}^{\prime}-\mathrm{Si}-(\mathrm{RO})_{3}$. The possibility of a convenient choice of the organic bridging groups within the porous frameworks provides a variety of desirable properties such as biodegradability, biocompatibility, varied hydrophobicity/hydrophilicity, and amphiphilicity to the PMO materials with an extended application potential, especially in immobilization, delivery, adsorption, and gas capture [49-51]. Methylene-bridged PMO (M-PMO) is a member of the PMOs family from both the structural and application points of view. Methylene is the only organic moiety that can be incorporated into the microporous networks and it offers also good chemical post-modifications. Despite this brilliant history of PMOs as remarkable nanovehicles, there is no report yet on the applying of this nanosystem for RNP delivery [52, 53].

In this study, a novel delivery nanosystem has been introduced to enhance the efficacy of the CRISPR-Cas9 complex-based gene-editing. Therefore, a bi-functionalized aminoguanidine-PEGylated PMO (AGu@PEG ${ }_{1500^{-}}$ PMO) has been proposed as a promising nanocarrier with high potential for RNP delivery. The useful features such as water solubility, FDA-approval, nontoxicity, nonantigenicity, and non-immunogenicity make polyethylene glycol (PEG) an applicable compound for carrier design. The PEGylated nanocarriers have been routinely applied to improve the stability, permeability, retention effect, and blood circulation of nanoparticles [54, 55]. Therefore, herein, the integrated three-dimensional cubic Ia3d KIT-6-like methylene-bridged PMO was furnished by PEG, and followed by further surface manipulation through aminoguanidine (AGu) grafting to obtain AGu@ $\mathrm{PEG}_{1500}$-PMO as the porous nanocarrier. The efficiency and reliability of RNP@AGu@PEG 1500 -PMO were determined in a GFP gene knock-out of GFP-HT1080 cells.

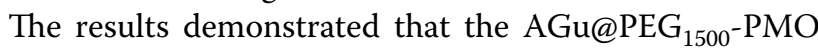
nanosystem could efficiently transfer the RNP into the GFP-HT1080 cells and substantially could decrease GFP in the target cells. The results have suggested the modified PMOs as very promising platforms for design a multifunctional nanosystem to efficiently deliver RNP. 


\section{Experimental \\ Materials}

Chloropropyltriethoxysilane (CPTES), polyethylene glycol ( $\mathrm{PEG}_{\mathrm{MW}=1500}$ ), Pluronic P123 (poly (alkylene oxide)-based triblock copolymer, $\mathrm{EO}_{20} \mathrm{PO}_{70} \mathrm{EO}_{20}$ ), tetraethylorthosilicate (TEOS), organosilane, 3-(triethoxysilyl) propyl isocyanate $95 \%$ (TESPIC), and the other materials were purchased from Sigma-Aldrich unless otherwise specified. 1, 2-bis(triethoxysilyl) methylene (BTESM, 97\%) was from Gelest. The required solutions was prepared using deionized water (DW). The success of the functionalization processes was confirmed using ATRFTIR (Attenuated Total Reflectance-Fourier Transform Infrared Spectroscopy, Thermo, AVATAR, USA) with spectroscopic grade $\mathrm{KBr}$ in the range of $4000-400 \mathrm{~cm}^{-1}$. The study of the morphology and size of porous nanomaterials were performed using SEM (scanning electron microscopy, Hitachi S-4800 II, Japan) and TEM (transmission electron microscopy, Philips EM208S 100KV). A BELSORP mini-II apparatus at liquid nitrogen temperature $(77 \mathrm{~K})$, as a volumetric adsorption measurement instrument was used for nitrogen adsorption measurements of NPs. Thermogravimetric analyses (TGA, TA Instrument; model SDT Q600) from 25 to $600{ }^{\circ} \mathrm{C}$ $\left(10{ }^{\circ} \mathrm{C} \cdot \mathrm{min}^{-1}\right)$ were used to study the thermal behaviour of the porous nanomaterials. Small-angle X-ray diffraction (XRD) was performed using a diffractometer (PhilipsX'pert 1710, CuK $\alpha(\alpha=1.54056 \AA ̊$ ). Dynamic light scattering (DLS, Particle Meterix Stabilizer 200, Germany) was utilized to determine the hydrolytic size distribution of NPs. For measuring the zeta potential of nanomaterials, a Nanosizer (Zeta sizer Nano ZS90, Malvern Instruments Ltd., Malvern, UK) was used. Thermo Scientific Multiskan spectrum was utilized for SDSPAGE gel scanning. A confocal laser microscope (CLSM, LSM 710, CarlZeiss, Oberlochen, Germany) was used to image the cellular uptake of the delivery nanosystems.

\section{Preparation of $\mathrm{PEG}_{1500}$-silane}

$\mathrm{PEG}_{1500}$-silane was prepared according to the nucleophilic addition reaction between the hydroxyl $(-\mathrm{OH})$ group from $\mathrm{PEG}_{1500}$ with the isocyanate (-NCO) function from TESPIC [56]. Briefly, TESPIC $(2.47 \mathrm{~g}, 10 \mathrm{mmol})$ was poured into a solution of $\mathrm{PEG}_{1500}(10 \mathrm{mmol})$ in dry pyridine $(50 \mathrm{~mL})$, and it was then stirred at $70{ }^{\circ} \mathrm{C}$ with vigorous stirring under argon atmosphere for $24 \mathrm{~h}$. Then the solvent was evaporated. The resultant solid was repeatedly washed with n-hexane, and then recrystallized from $\mathrm{Et}_{2} \mathrm{O}$ at $0{ }^{\circ} \mathrm{C}$. $\mathrm{PEG}_{1500}$-silane was filtered as the white waxen solid and then dried at room temperature in a vacuum oven.
Preparation of nanocarrier (AGu@PEG ${ }_{1500}-\mathrm{PMO}$ ) PEGylated methylene-bridged PMO (PEG1500-PMO)

Large pore M-PMO was prepared according to the previously reported method with a slight modification using bis-(triethoxysilyl) methane (BTESM) organosilane and tetraethyl orthosilicate (TEOS) TEOS as the Si resources [57]. Briefly, n-BuOH (24.5 mmol, $1.8 \mathrm{~g}$ ) was added to a mixture of P123 $\left(\mathrm{M}_{\mathrm{w}}=5800,1.9 \mathrm{~g}, 0.34 \mathrm{mmol}\right), \mathrm{H}_{2} \mathrm{O}$ (72.0 g, $4 \mathrm{~mol})$, and $\mathrm{HCl}(2 \mathrm{M})$, and then allowed to stir at $35^{\circ} \mathrm{C}$ for $60 \mathrm{~min}$. Then BTESM and TEOS were separately poured into the later mixture, such a way that the molar ratio in the final mixture was 0.25 TEOS: 0.25 BTESM: 0.034 P123: $1.0 \mathrm{HCl}: 2.45 \mathrm{BuOH}: 400 \mathrm{H}_{2} \mathrm{O}$. The later mixture was stirred for a day at $35^{\circ} \mathrm{C}$, and followed by keeping without stirring in a Teflon coated autoclave at $130{ }^{\circ} \mathrm{C}$ for 3 days. The residual solid was washed thoroughly with $\mathrm{H}_{2} \mathrm{O}$, separated, and then dried in the air atmosphere to give as-synthesized M-PMO. Subsequently, the copolymer templating agent from the PMO materials was removed through two solvent extraction processes. First step was performed as follows: $200 \mathrm{mg}$ of as-synthesized PEGylated sample was stirred in an acid solution containing $100 \mathrm{~mL}$ of $\mathrm{EtOH}$ and $3.0 \mathrm{~g}$ of $\mathrm{HCl}$ at $60{ }^{\circ} \mathrm{C}$ for $12 \mathrm{~h}$, then the solid was separated and dried. Next, for further solvent extraction, $\mathrm{H}_{2} \mathrm{SO}_{4}$ treatment was done on the resultant solid $[58,59]$ by two successive circles with $100 \mathrm{~mL}$ of $48 \mathrm{wt} \% \mathrm{H}_{2} \mathrm{SO}_{4}$ solution per $1.0 \mathrm{~g}$ of the as-synthesized sample at $90^{\circ} \mathrm{C}$ for $12 \mathrm{~h}$. The resultant solid was collected by filtration and washed until the eluent became neutral. Then the residual solid was dried under vacuum condition at $25^{\circ} \mathrm{C}$ to achieve M-PMO.

Then $\mathrm{PEG}_{1500^{-}}$silane $(1.5 \mathrm{mmol})$ dissolved in toluene $(5.0 \mathrm{~mL})$ was poured in a suspension of M-PMO $(100 \mathrm{mg})$ in toluene $(20 \mathrm{~mL})$, followed by pouring $500 \mu \mathrm{L}$ of $\mathrm{H}_{2} \mathrm{O}$ into the mixture, and it was gently stirred at $100{ }^{\circ} \mathrm{C}$. After $18 \mathrm{~h}$ stirring and cooling down, the residue was centrifuged, washed with $\mathrm{EtOH}$, and dried under vacuum condition at $25^{\circ} \mathrm{C}$ for $12 \mathrm{~h}$ to give PEGylated methylenebridged PMO ( $\left.\mathrm{PEG}_{1500}-\mathrm{PMO}\right)$.

\section{Synthesis of AGu@PEG1500-PMO}

CPTES (2.0 mmol, $0.397 \mathrm{~g}$ ) was added to a suspension of purified $\mathrm{PEG}_{1500}-\mathrm{PMO}(100 \mathrm{mg})$ in $50 \mathrm{~mL}$ toluene and refluxed at $111{ }^{\circ} \mathrm{C}$ for $24 \mathrm{~h}$. The solid was centrifuged and it was dried under vacuum to give chloropropyl functionalized $\mathrm{PEG}_{1500}-\mathrm{PMO}$ (denoted as $\mathrm{CP} @$ $\mathrm{PEG}_{1500}-\mathrm{PMO}$ ) [60]. Next, aminoguanidine hydrochloride ( $\mathrm{AGu}$. $\mathrm{HCl}, 2.5 \mathrm{mmol}, 0.22 \mathrm{~g}$ ) and sodium carbonate $(2.5 \mathrm{mmol}, 0.265 \mathrm{mg})$ were mixed with $100 \mathrm{mg}$ of the $\mathrm{CP} @ \mathrm{PEG}_{1500}-\mathrm{PMO}$ in $50 \mathrm{~mL} \mathrm{DMF}$ and allowed to stir at $90{ }^{\circ} \mathrm{C}$ overnight. Finally, the obtained fine pale yellow powder was filtered off as bi-functionalized 
aminoguanidine-PEGylated PMO (AGu@PEG $\left.{ }_{1500}-\mathrm{PMO}\right)$, washed with $\mathrm{EtOH}$ or acetone, and then dried [61].

\section{RNP loading}

To optimize the RNP loading reaction, the effect of two factors including the loading time and the amounts of RNP were examined. As the optimal condition, typically, RNP (30, 60, 120, and $240 \mathrm{nM}$ ) was added to a suspension containing $\mathrm{AGu} @ \mathrm{PEG}_{1500}-\mathrm{PMO}$ or $\mathrm{PEG}_{1500}-\mathrm{PMO}$ $(1.0 \mathrm{mg}$ ) and $1 \mathrm{~mL}$ of the assembly buffer $\mathrm{pH} 7.5$ (Tris$\mathrm{HCl}(10 \mathrm{mM}), \mathrm{M} \mathrm{NaCl}(100 \mathrm{~m})$, EDTA $(1 \mathrm{mM})$, and DTT $(1 \mathrm{mM})$ ) [62] at $37{ }^{\circ} \mathrm{C}$, and the suspension was then shaken at $4{ }^{\circ} \mathrm{C}$ for $0,1,3,6$, and $12 \mathrm{~h}$. The residual was centrifuged and thoroughly washed with assembly buffer for removal of the possible un-immobilized RNP to give the pure powdery product as RNP@AGu@PEG ${ }_{1500^{-}}$ PMO (RNP loaded onto aminoguanidine functionalized PEGylated PMO). Finally, the immobilization efficacy (IE) was determined using the gel SDS-PAGE (Additional file 1: Figure S1) [63]. The quantification of gel bonds was performed using image $J$ software $[64,65]$. The IE was calculated using (Eq. 1) where $\mathrm{C}_{\mathrm{i}}$ and $\mathrm{C}_{\mathrm{s}}$ are the initial and final RNP concentrations in the release media, respectively.

$$
\operatorname{IE}(\%)=\mathrm{C}_{\mathrm{i}}--\left(\mathrm{C}_{\mathrm{s}} / \mathrm{C}_{\mathrm{i}}\right) \times 100
$$

Equation 1 The equation for calculating the immobilization efficacy (IE).

\section{In vitro RNP release test}

RNP@AGu@PEG ${ }_{1500}$-PMO (2.0 mg) was added into a $2 \mathrm{~mL}$ of phosphate buffer solution (PBS) or citric acidsodium citrate buffer solution as $\mathrm{pH} 7.5$ and $\mathrm{pH} 5.8$ conditions, respectively. The release was investigated using a water bath at $37{ }^{\circ} \mathrm{C}$ under a gentle shaking. The sampling was done at predetermined times $0,2,4,8,12,24$, and $72 \mathrm{~h}$ and replaced the same amount of fresh PBS to maintain the sink condition. In each sampling, $20 \mu \mathrm{L}$ of the suspension was drawn out. The quantity of RNP in the samples was measured using the SDS-PAGE gel (Additional file 1: Figure S2) $[64,65]$. A standard curve of RNP (25-200 ng) was generated for determination of the concentration of RNP released from RNP@AGu@PEG ${ }_{1500^{-}}$ PMO. Equation 2 was used to calculate the cumulative release $(R, \%)$, where $C_{i}$ and $C_{n}$ are the initial and final RNP concentration in the media, respectively. $\mathrm{V}$ and $\mathrm{V}_{0}$ are the volume of the release sampling and the total volume of the mixture; and $\mathrm{m}$ is the total mass of loaded RNP.

$$
R=\frac{V \sum_{i}^{n-i} C_{i}+V_{0} C_{n}}{m_{\mathrm{drug}}} \times 100
$$

Equation 2. The equation for calculating the cumulative release of RNP.

\section{Cloning, expression, and purification of S. pyogenes Cas9}

The codon-optimization of 3' FLAG-NLS-Streptococcus pyogenes (SP) Cas9-NLS with C-terminal His6 tag was done by Codon Optimization On-Line (COOL) tool [66]. The 4299 codon-optimized synthetic nucleotide sequence (NdeI-3'FLAG-NLS-SpCas9-NLS-His6-HindIII) was cloned between NdeI and HindIII restriction sites of the pET-28a vector (Additional file 1: TableS1). The E. coli BL21 STAR (DE3)-competent cells (Life Technologies, USA) were transformed with pET-28a-Cas9 vector and was grown in Luria-Bertani (LB) broth supplemented with $100 \mathrm{mg} \cdot \mathrm{mL}^{-1}$ of ampicillin at $37^{\circ} \mathrm{C}$ overnight. The cells were diluted 100 -fold with the fresh growth medium and incubated at $37^{\circ} \mathrm{C}$ to $\mathrm{OD} 600=\sim 0.8$, then isopropyl $\beta$-d-1-thiogalactopyranoside (IPTG) was added to induce Cas9 expression and the culture was incubated at $22{ }^{\circ} \mathrm{C}$ for $\sim 20 \mathrm{~h}$. Afterward, the cells were collected by centrifuging for $30 \mathrm{~min}$ at $4{ }^{\circ} \mathrm{C}$. The Cas 9 protein was purified under native condition using the Qiagen Ni-NTA Fast Start Kit according to the manufacturer's manual. The Cas9 concentration was quantified by bicinchoninic acid (BCA) assay (Pierce Biotechnology, Rockford, IL, USA) and analyzed by SDS-PAGE (Additional file 1: Figure S3).

\section{In vitro transcription of sgRNAs}

Single-stranded oligos coded for the target GFP gene sequence were designed and synthesized according to Gene Art Precision gRNA Synthesis Kit (Thermo Fisher, USA) instructions (Additional file 1: TableS1). The gRNA template was assembled by addition of the reaction components in the order given in the protocol. The PCR cycles were performed as follows: initial denaturation at $98{ }^{\circ} \mathrm{C}$ for $10 \mathrm{~s}, 32$ cycles of denaturation at $98^{\circ} \mathrm{C}$ for $5 \mathrm{~s}$, annealing at $55{ }^{\circ} \mathrm{C}$ for $15 \mathrm{~s}$, and a final extension at $72{ }^{\circ} \mathrm{C}$ for 1 min. Next, based on the kit instructions the appropriate amount of PCR product was employed as a template in the in-vitro transcription (IVT) reaction and then the DNA template was removed by adding $1 \mu \mathrm{L}$ DNaseA and incubation at $37{ }^{\circ} \mathrm{C}$ for $15 \mathrm{~min}$. The in-vitro transcribed sgRNA was then purified, quantified with Nanodrop 2000c (Thermo Scientific), and analyzed by the agarose gel electrophoresis (Additional file 1: Figure S4).

\section{Preparation of GFP-HT1080 cells}

The virus-containing pLenti6.3-To-V5-Dest-GFP vector was transduced into HT1080 cells (ATCC-CCL-121 ${ }^{\mathrm{TM}}$ ) 
using polybrene as described previously [67]. Briefly, HT1080 cells were plated at a density of $1 \times 10^{5}$ cells per $\mathrm{mL}$ in complete DMEM media containing $10 \%$ FBS at $37{ }^{\circ} \mathrm{C}$ in $5 \% \mathrm{CO}_{2}$ and allowed to adhere overnight. Then, an indicated multiplicity of infection (MOI) of 2 of the virus was added in the presence of $6 \mu \mathrm{g} \cdot \mathrm{mL}^{-1}$ of polybrene and the cells were incubated overnight. Afterward, the media was replaced with fresh media with no virus and the cells were incubated for a further $24 \mathrm{~h}$. Next, the cells were subjected to $1 \mu \mathrm{g} \cdot \mathrm{mL}^{-1}$ blasticidin for the selection of the stable GFP-HT1080 cells for 9 days. The GFP-HT1080 cells have been sufficiently expanded. Single cells of GFP-HT1080 cells were then plated and cultured in individual wells of a 96-well plate for 13 days (Additional file 1: Figure S5) and expanded to generate monoclonal GFP-HT1080 cell lines.

\section{MTT cell viability assay}

The effects of AGu@PEG 1500 -PMO and RNP@AGu@ $\mathrm{PEG}_{1500}$-PMO on the viability of GFP-HT1080, HT1080, and MCF10A cells were assessed using the MTT assay in which the succinate dehydrogenase mitochondrial activity was determined as a creation of the cell viability. Following exposure of different concentrations of $\mathrm{AGu@}$ $\mathrm{PEG}_{1500}$-PMO and RNP@AGu@PEG ${ }_{1500}-\mathrm{PMO}$, the cells were incubated with MTT $\left(20 \mu \mathrm{L}\right.$ of $5 \mathrm{mg} \cdot \mathrm{mL}^{-1}$ stock per well) for $4 \mathrm{~h}$. Cytotoxicity was determined by measuring the reduction of the yellowish water-soluble MTT to water-insoluble MTT formazan. After the removal of the medium, the resulted formazan crystals were dissolved by the addition of DMSO $(200 \mu \mathrm{L})$ into each well. Afterward, the optical density was detected by a microplate reader (Synergy2, BioTek, and Winooski, VT, USA) at $570 \mathrm{~nm}$. As a control, the sample without NPs (AGu@ $\mathrm{PEG}_{1500}-\mathrm{PMO}$ or RNP@AGu@PEG $\left.{ }_{1500}-\mathrm{PMO}\right)$ was set, at $100 \%$ viability.

\section{GFP expression assessment by flow cytometry}

GFP transfected HT1080 cells were seeded in 6 wells plate at a density of $15 \times 10^{4}$ cells. The cells were cultured in DMEM medium containing 10\% FBS and 0.1\% penicillin-streptomycin at $37{ }^{\circ} \mathrm{C}$ in a humidified $5 \% \mathrm{CO}_{2}$ atmosphere. After cell attachment, those were treated separately with free RNP, AGu@PEG ${ }_{1500}-\mathrm{PMO}(100 \mu \mathrm{g}$. $\left.\mathrm{mL}^{-1}\right)$, and RNP@AGu@PEG ${ }_{1500}-\mathrm{PMO}\left(100 \mu \mathrm{g} \cdot \mathrm{mL}^{-1}\right)$ dispersed in DMEM for $4 \mathrm{~h}$. Then these media were replaced by fresh DMEM media. The cells were incubated for 3 days, finally washed, and analyzed using a BD FACSCalibur flow cytometer (BD Bioscience, San Jose, CA, USA).

\section{In vitro DNA cleavage assay}

Target GFP gene was amplified by PCR from pLenti6.3To-V5-Dest-GFP vector using GFP amplification primers, and PCR program as follows: $95^{\circ} \mathrm{C}$ for $5 \mathrm{~min}, 35$ cycles of $95^{\circ} \mathrm{C}$ for $30 \mathrm{~s}, 60^{\circ} \mathrm{C}$ for $30 \mathrm{~s}, 72{ }^{\circ} \mathrm{C}$ for $60 \mathrm{~s}$, and the final step of $72{ }^{\circ} \mathrm{C}$ for $10 \mathrm{~min}$. Then the amplification product was purified with phenol-chloroform and target DNA cleaved by Cas9-sgRNA. Cas9 and sgRNA $(1: 1,100 \mathrm{nM})$ were mixed in the assembly buffer [62] and incubated at $37{ }^{\circ} \mathrm{C}$ for $1 \mathrm{~h}$. Afterward, the dsDNA (the target GFP sequence, $200 \mathrm{ng}$ ) was cleaved with $100 \mathrm{nM}$ of Cas9-gRNA complex in buffer solution pH 7.5 (Tris- $\mathrm{HCl}$ $(10 \mathrm{mM}), \mathrm{NaCl}(100 \mathrm{mM}), \mathrm{MgCl}_{2}(10 \mathrm{mM})$, and DTT $(1 \mathrm{mM}))$ for $1 \mathrm{~h}$ at $37^{\circ} \mathrm{C}$ in a $100 \mu \mathrm{L}$ reaction volume. The polyacrylamide gel electrophoresis was used to analysis the digested DNA.

\section{Cellular uptake study}

Sulforhodamine B ( $\mathrm{SrB})$ was encapsulated on the nanoporous AGu@PEG ${ }_{1500}-\mathrm{PMO}$ nanocarrier to confirm the feasibility of its cellular uptake [68]. Briefly, SrB (1 mg) dissolved in DMSO $(1 \mathrm{~mL})$ was added to a suspension of AGu@PEG ${ }_{1500}$-PMO (5 mg) in DMSO (2 mL). After $2 \mathrm{~h}$ stirring, the residual solid was centrifuged, washed, and then dried in a vacuum oven to obtain SrB@AGu@ $\mathrm{PEG}_{1500}$-PMO. The GFP-HT1080 cells were seeded onto $35 \mathrm{~mm}$ cover glass-bottom culture dishes (NEST Science, Wuxi, China) with $5 \times 10^{4}$ cells per well in complete DMEM $(2 \mathrm{~mL})$ overnight. The medium was replaced with fresh DMEM and then SrB@AGu@PEG ${ }_{1500}-\mathrm{PMO}$ was added at an equivalent concentration per well. After incubation for 1, 2, 4, and $6 \mathrm{~h}$, the cells were washed with PBS repeatedly and fixed with $4 \%$ paraformaldehyde for $15 \mathrm{~min}$ and then the cells were again washed with PBS. Then their nucleus were stained with DAPI and then washed thoroughly with PBS. A confocal laser scanning microscope (Zeiss LSM 800, Carl Zeiss- Jena, Germany) was used to observe the cells. The excitation for $\mathrm{SrB}$ was at $543 \mathrm{~nm}$ and that of DAPI was at $365 \mathrm{~nm}$.

\section{Statistical analysis}

The results have presented as mean \pm SD Statistical analysis was performed using a two-tailed student's t-test. All experiments were performed in three replicates. The difference between experimental and control groups was considered statistically significant when $p<0.01$. Experimental data were analyzed using SAS v.9.1 software and graphs were drawn using Microsoft Office Excel 2010.

\section{Results and discussion}

Owing to the superiorities of silica-based nanoporous materials, this family of nanoporous materials is of great interest as a nanocarrier for the efficient delivery of 
different biological cargoes. We investigated the potent of the bi-functionalized large pore I3ad mesoporousbased nanocarrier as a biocompatible and promising RNP delivery nano-system. To this, M-PMO was prepared via hydrothermal method using BTESM/TEOS and $\mathrm{P} 123 / \mathrm{n}-\mathrm{BuOH}$ as Si resource and surfactant/co-surfactant, respectively [57]. Then the soft templating-agent was removed via acidic solvent extraction. To reach a larger pore size, $\mathrm{H}_{2} \mathrm{SO}_{4}$ treatment was accomplished [58, 59]. To achieve improved biocompatibility, the surface of M-PMO nanocarrier modified by covalent grafting of polyethylene glycol (PEG) as a biodegradable group. Notably, the surface chemistry of the pores works as a key point in achieving a superior cargo loading as a result of a suitable interaction between the surface of nano-pores with the loaded molecules through non-covalent bindings such as electrostatic bonding, hydrogen bonding, $\pi-\pi$ bonding and etc. [69]. In this context, the surface of the M-PMO nanocarrier was next furnished with aminoguanidine moieties. Schematically, the RNP@AGu@ $\mathrm{PEG}_{1500}-\mathrm{PMO}$ was prepared as shown in Fig. 1. RNP@ $\mathrm{AGu} @ \mathrm{PEG}_{1500}-\mathrm{PMO}$ was able to enter the cell through the pore formation or endosomal escape that was followed by slow release of RNP because of the proton sponge effect of aminoguanidine. The samples were comprehensively characterized using different techniques such as XRD, TGA, FT-IR, TEM, SEM, DLS, AFM, nitrogen sorption measurements, and zeta potential analysis.

The ordered mesostructured and morphology of M-PMO were recognized by SEM and TEM (Fig. 2). TEM was utilized to illustrate the order of the mesostructured framework and particle size distribution (PSD) (Fig. 2a and d). The uniformity of meso-channels with cubic order of M-PMO is appeared and the PSD has been provided using a sample composed of more than 100 particles population. This histogram showed the M-PMO particles have an average diameter of $67.4 \pm 2.8 \mathrm{~nm}$ (Fig. 2d). Also, the DLS results revealed that the hydrodynamic diameter of M-PMO sample was about $132 \mathrm{~nm}$ which could meet the required stability and cell uptake efficiency (Fig. 2e) [70]. The particle diameters obtained by DLS were larger than those determined by TEM. This could be due to the fact that DLS measurement provides the average hydrodynamic

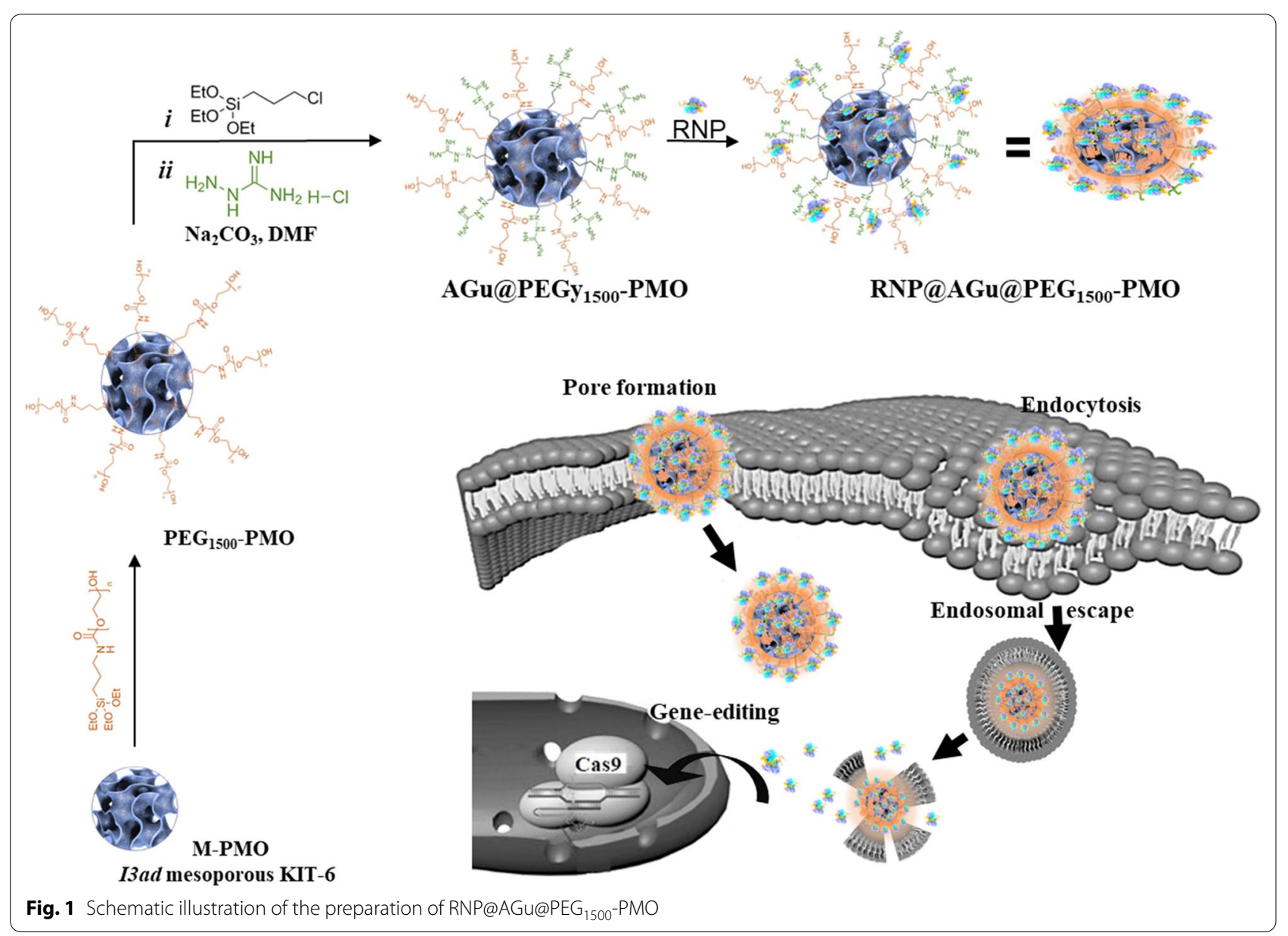



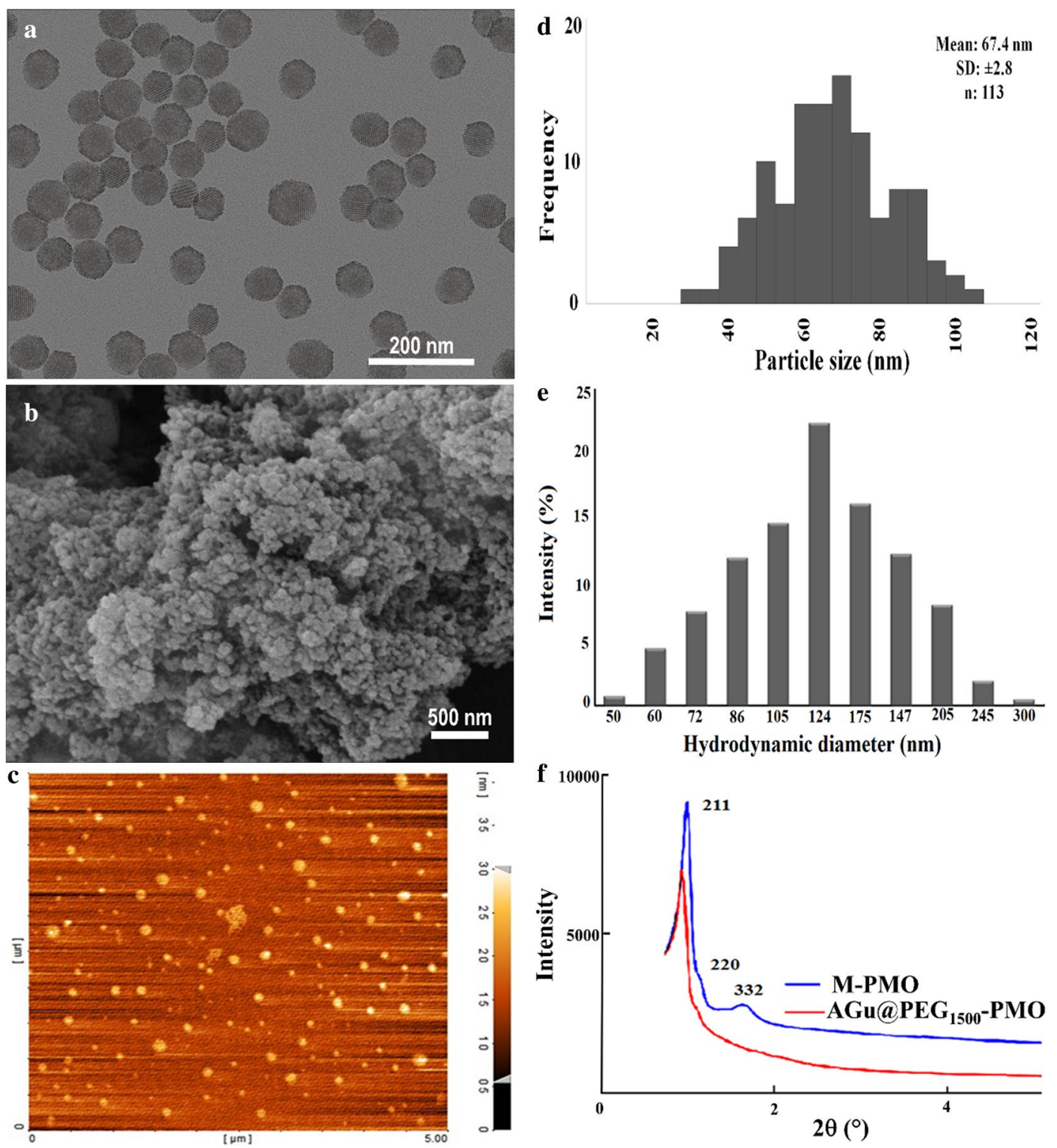

Fig. 2 a TEM, b SEM c AFM, d the particle size distribution histogram obtained from the TEM data, e the particle size distribution obtained from the DLS data, and $\mathbf{f}$ XRD pattern of M-PMO

diameter of the hydrated NPs, and the TEM yields the size distribution of the dehydrated NPs [71]. The $\mathrm{d}_{211}$-spacing of M-PMO was calculated from the small-angle XRD result using a Bragg's equation and the unit cell parameter given by the $a_{0}=d 211 \sqrt{ } 6$ was $22.3 \mathrm{~nm}$. From the TEM images, the pore size of the $\mathrm{M}$-PMO was estimated about $\sim 9.3 \mathrm{~nm}$ that is in agreement with the results of the sorption analysis and XRD [72]. The SEM image showed that AGu@PEG ${ }_{1500}-\mathrm{PMO}$ was spherical with an average diameter below $100 \mathrm{~nm}$ (Fig. 2b) and the 3D topography image resulted from AFM analysis indicated a uniform deposition pattern in the case of M-PMO (Fig. 2c). The small-angle XRD patterns of $\mathrm{M}-\mathrm{PMO}$ and $\mathrm{AGu@PEG}{ }_{1500}-\mathrm{PMO}$ have shown similar pattern including the reflections of 211 , 220 , and 332 that are observed at $0.97^{\circ}(2 \theta), 1.18^{\circ}(2 \theta)$ and $1.87^{\circ}(2 \theta)$, respectively (Fig. 2f). Accordingly, these patterns agreeing with the $(I a-3 d)$ symmetry and indicate the presence of well-defined pores before and after surface modification of M-PMO [73, 74]. The observed decrease in the intensity of the reflections, without change in their position and pattern suggests the success of functionalization as well as the retention of the

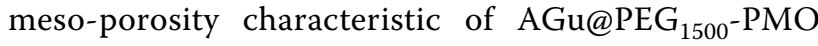
during surface modification. 
To demonstrate the suitability of $\mathrm{AGu} @ \mathrm{PEG}_{1500}-\mathrm{PMO}$ as a nanocarrier for RNP delivery, its RNP loading and release efficacy were investigated and compared to that of $\mathrm{PEG}_{1500}-\mathrm{PMO}$ as the unmodified nanocarrier. Different conditions including RNP concentrations and loading times were investigated. These results showed that the loading efficiency of about $100 \%$ achieved within $3 \mathrm{~h}$ for all the examined RNP concentrations. Notably, no change was observed in the loading efficiency of AGu@ $\mathrm{PEG}_{1500}-\mathrm{PMO}$ by increasing the RNP concentrations. Figure $3 \mathrm{a}$ presents the amount of RNP loading at physiological pH. The results have demonstrated that AGu@ $\mathrm{PEG}_{1500}-\mathrm{PMO}$ was more efficient than $\mathrm{PEG}_{1500}$-PMO in RNP loading. The cumulative release of RNP from RNP@ $\mathrm{AGu} @ \mathrm{PEG}_{1500}-\mathrm{PMO}$ at $\mathrm{pH} 7.5$ and 5.8 were more than $60 \%$ and $85 \%$ after $24 \mathrm{~h}$, respectively (Fig. $3 \mathrm{~b}$ ).

The efficiency of protein encapsulation depends on the chemistry of the NPs surface and their surface charges, therefore, this result could be explained by the introduction of the grafted aminoguanidine ( $\mathrm{AGu}$ ) groups on the surface of nanopores. Tu, et.al, reported that for the negatively charged proteins, the confinement in the modified MSNs with positive surface charge was more efficient compared to the confinement in unmodified MSNs [75-78]. It is concluded that the amount of negatively charged protein encapsulation increases by embedding of a positively charged moiety such as aminoguanidine $(\mathrm{AGu})$ onto the nanocarrier surface. $\mathrm{AGu}_{\mathrm{P}} \mathrm{PEG}_{1500}-\mathrm{PMO}$ showed a higher RNP loading capacity due to the negative surface charge of RNP $-23.8 \mathrm{mV}$. As seen in Fig. 3c, a negative surface charge $(-25 \mathrm{mV})$ and a positive charge $(+28.2 \mathrm{mV})$ was observed by the zeta-potential analysis of $\mathrm{PEG}_{1500}-\mathrm{PMO}$ and $\mathrm{AGu@PEG}{ }_{1500}-\mathrm{PMO}$, respectively. The results suggest that the RNP loading was accomplished via the electrostatic interactions and hydrogenbonding interactions between $(-\mathrm{N}-\mathrm{H})$ and $\left(-\mathrm{CO}_{2} \mathrm{H}\right)$ found in the protein with the aminoguanidine and PEG moieties from the nanocarrier [69]. This could be explained by the electrostatic bonding between the positively charged surface of $\mathrm{AGu} @ \mathrm{PEG}_{1500}-\mathrm{PMO}$ and the negatively charged RNP and resulted from aminoguanidyl groups. It is also interesting to note that RNP can be efficiently entrapped into the aminoguanidine modified mesoporous network in comparison with the unmodified analogue.
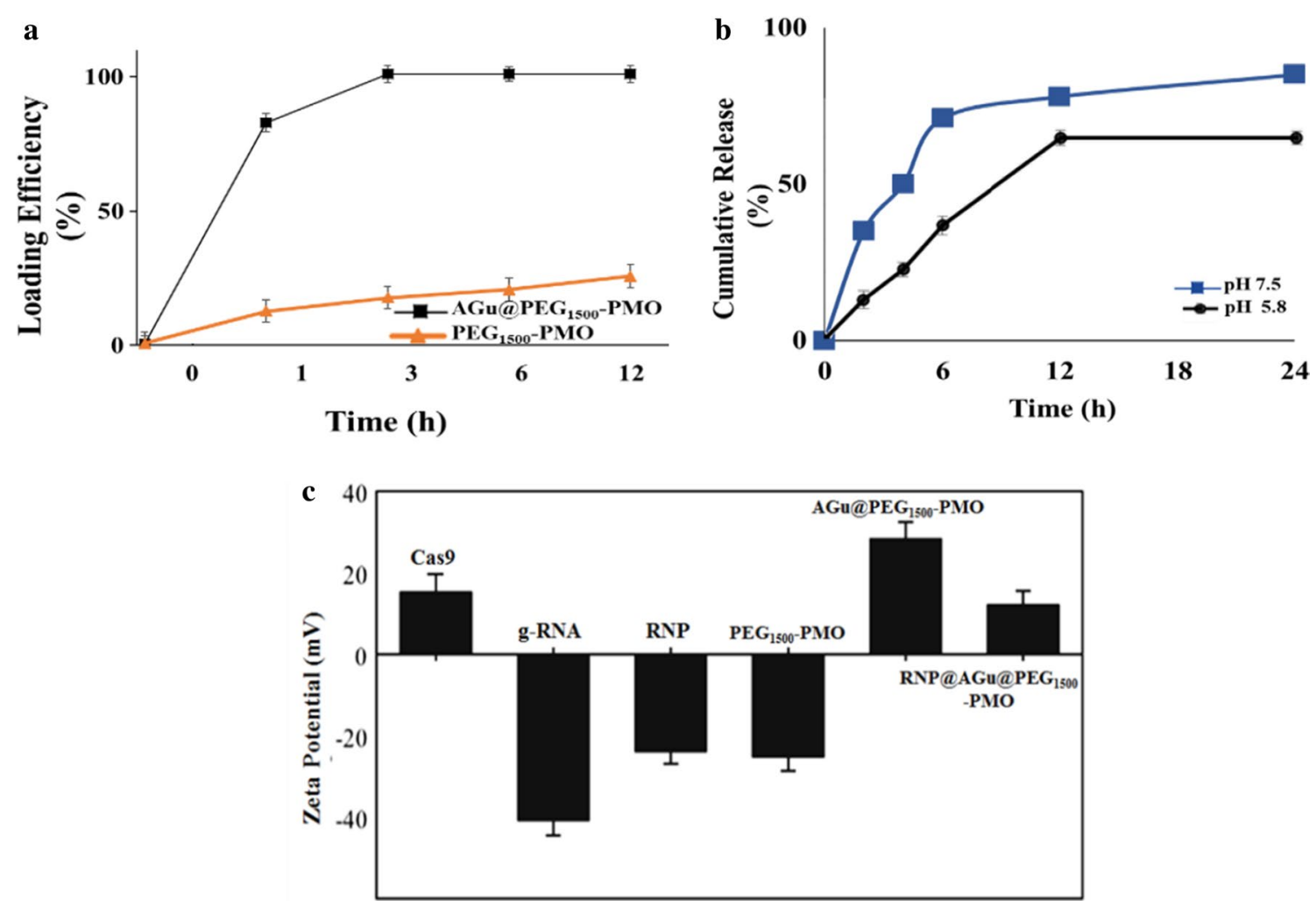

Fig. 3 a Loading profile of RNP on nanocarrier at $\mathrm{PH}=7.5$ using $\mathrm{AGU}_{\mathrm{N}} \mathrm{PEG} \mathrm{G}_{1500}-\mathrm{PMO}$ and $\mathrm{PEG}_{1500}-\mathrm{PMO}$; $\mathbf{b}$ the release profile of RNP from RNP@

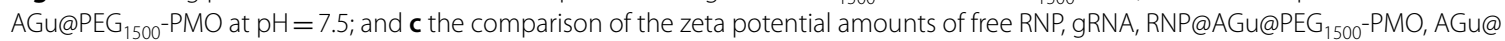
$\mathrm{PEG}_{1500}-\mathrm{PMO}, \mathrm{PEG}_{1500}-\mathrm{PMO}$, and Cas9. Bars represent mean $\pm \mathrm{SD}(\mathrm{n}=3)$ 
The synthesized PMO and modified PMO-based nanomaterials were characterized by ATR-FT-IR spectroscopy (Fig. 4a). In the FTIR spectrum of M-PMO sample, the broad absorption peaks at around 3430 and $924 \mathrm{~cm}^{-1}$ could be assigned to the stretching and bending vibrations of hydroxyl $(\mathrm{O}-\mathrm{H})$ bonds found in the surface $\mathrm{Si}-\mathrm{OH}$ and the absorbed water molecules, respectively [79]. The strong peaks at about 1125 and $1085 \mathrm{~cm}^{-1}$ could be ascribed to the stretching vibrations of the organic bridged $\left(\mathrm{Si}-\mathrm{O}-\mathrm{CH}_{2}-\mathrm{O}-\mathrm{Si}\right)$ and $\mathrm{Si}-\mathrm{O}-\mathrm{Si}$ bonds on the Si-skeleton of PMO, respectively. The peak at about $810 \mathrm{~cm}^{-1}$ could be ascribed to the symmetric stretching vibration of $\mathrm{Si}-\mathrm{O}$ bond in the siloxanes [80]. In the spectrum of $\mathrm{PEG}_{1500}-\mathrm{PMO}$, the band at around $2910 \mathrm{~cm}^{-1}$ could be attributed to stretching vibration of the aliphatic $\mathrm{C}-\mathrm{H}$ bonds of the PEG chain. Also, the appeared increase in the intensity of the band at $3430 \mathrm{~cm}^{-1}$ could be indexed to the stretching vibration of $\mathrm{O}-\mathrm{H}$ bond of the PEG chain. These evidences lead to the conclusion that the PMO frameworks were successfully modified by PEG moiety.
As seen in the spectrum of $\mathrm{AGu} @ \mathrm{PEG}_{1500^{-}} \mathrm{PMO}$, the bands at 2954, 2868, and $1020 \mathrm{~cm}^{-1}$ could be attributed to the vibrations of the $\mathrm{C}-\mathrm{H}$ bonds and the other band appeared at $1465 \mathrm{~cm}^{-1}$ could be related to the stretching vibration of the $\mathrm{C}-\mathrm{N}$ bonds, found in the grafted organic groups $(\mathrm{AGu})$ [67]. In the spectrum of RNP complex, the broadband at $3460 \mathrm{~cm}^{-1}$ and the peak at about $1640 \mathrm{~cm}^{-1}$ can be attributed to hydroxyl groups $(-\mathrm{OH})$ stretching vibrations and amine $(-\mathrm{NH})$ groups found in the RNA bases and proteins [81]. The peaks at 1540, $1440,1410,1330$, and $1210 \mathrm{~cm}^{-1}$ can be attributed to the stretching vibrations of pyrimidine and amino acid groups found in RNP complex [82]. The peaks at about 1070 and $1050 \mathrm{~cm}^{-1}$ can be assigned to the vibration of ribose $(\mathrm{C}-\mathrm{C}$ sugar) or associated with $\mathrm{P}-\mathrm{O} / \mathrm{C}-\mathrm{O}$ and $\mathrm{PO}_{2}$ group vibrations [83]. The appeared changes in the nucleobase and protein regions in the spectrum of RNP@ $\mathrm{AGu} @ \mathrm{PEG}_{1500}-\mathrm{PMO}$ has indicated that the interactions between RNP and NPs and the successful load of RNP has been loaded onto the AGu@PEG ${ }_{1500}$-PMO nanocarrier [84].
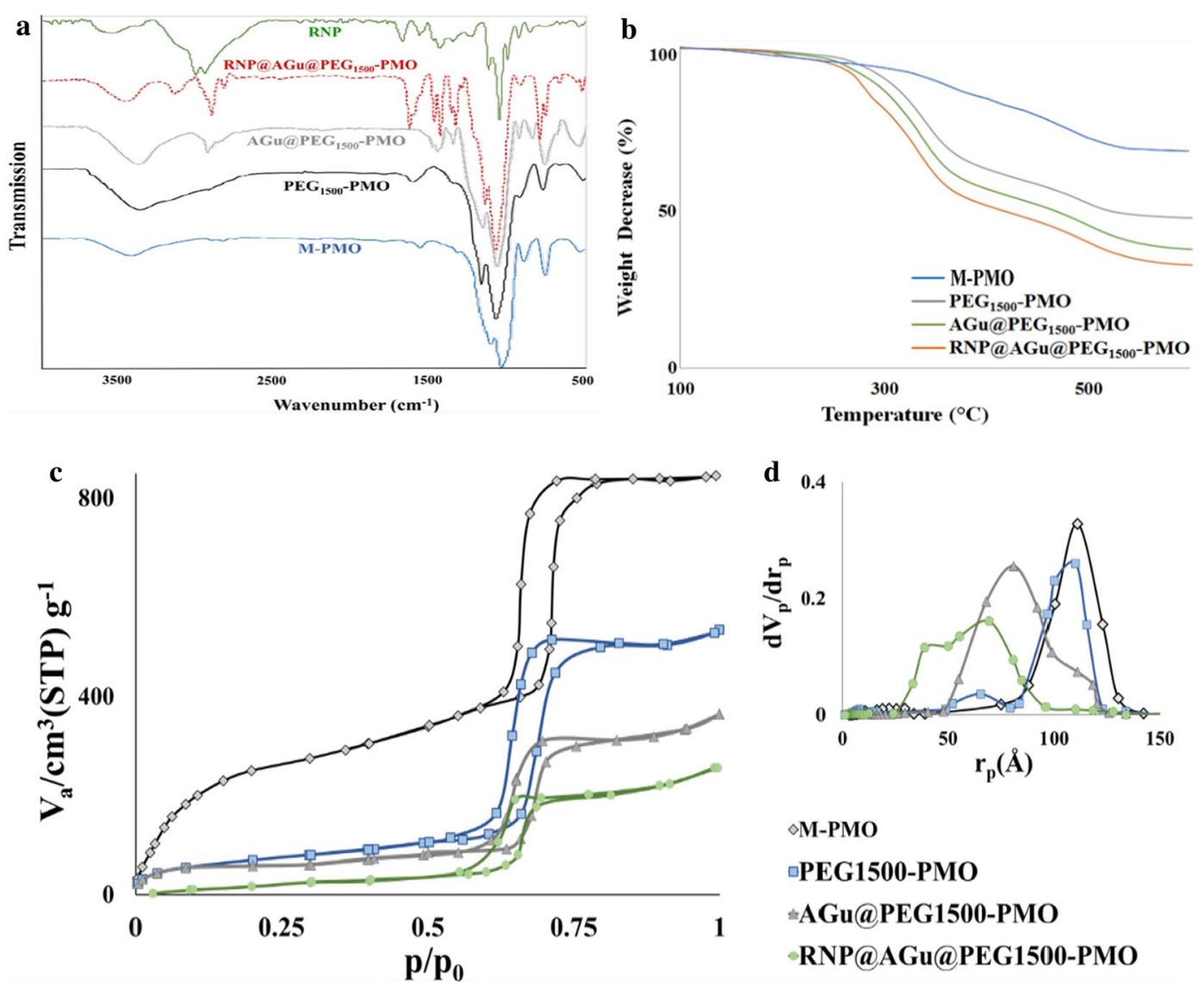

Fig. 4 a FTIR spectroscopy, $\mathbf{b}$ TGA, and $\mathrm{N}_{2}$ adsorption-desorption isotherms, and the BJH pore size distribution curves (inset d) of $M-P M O$, $\mathrm{PEG}_{1500}-\mathrm{PMO}$, AGu@PEG $1500-\mathrm{PMO}$, and RNP@AGu@PEG $1500-\mathrm{PMO}$ 
TGA analysis was utilized to measure the amount of aminoguanidyl moiety and immobilized RNP on the surface of $A G u @ P E G_{1500}-\mathrm{PMO}$ (Fig. 4b). TGA profiles of nanocarrier before and after RNP loading were shown in Fig. 4b. PMO nanomaterial showed a major weight loss from 400 to $600{ }^{\circ} \mathrm{C}$ that could be attributed to the dissociation of the organic bridged group of PMO [85]. Due to this boosted and thermal stability I3ad mesoporous structured-based nanocarrier (M-PMO) with large pores can be considered as qualified hosts for transferring different guests even under high-temperature conditions. In AGu@PEG 1500 -PMO, the peak from 290 to $395{ }^{\circ} \mathrm{C}$ could be indexed to the decomposition of the grafted organic groups. For RNP@AGu@PEG ${ }_{1500}-\mathrm{PMO}$, the first and second loss could be related to the elimination of water and the leaving of RNP and organic grafted linker, respectively. The amount of PEG, AGu, and RNP in RNP@AGu@PEG 1500 -PMO have been determined about $\sim 25, \sim 10$, and $\sim 5 \%$, respectively, as measured using TGA. These results has clearly shown that PMO with a convenient surface chemistry can work as a proper candidate for highly efficient loading of RNP).

The $\mathrm{N}_{2}$ adsorption-desorption isotherms of all of the nanomaterials have shown type IV with obvious H1 hysteresis cycles that confirm the presence of the channel-like porosity (Fig. 4c). The surface areas $\mathrm{S}_{\mathrm{BET}}$, were calculated using BET (Brunauer-Emmett-Teller) equation, and the total pore volume and average pore size were calculated using the BJH (Barrett-Joyner-Halenda) method (Fig. 4b). Based on the results, the surface area, averaged pore diameter, and total pore-volume of $\mathrm{PEG}_{1500}$-PMO were $\sim 421.91 \mathrm{~m}^{2} \cdot \mathrm{g}^{-1}, \sim 11 \mathrm{~nm}$, and 1.85 $\mathrm{cm}^{3} \cdot \mathrm{g}^{-1}$, respectively. During the surface modification of $\mathrm{PEG}_{1500}-\mathrm{PMO}$ and RNP loading to synthesize the RNP@ $\mathrm{AGu} @ \mathrm{PEG}_{1500}-\mathrm{PMO}$, a significant decrease was observed in all of these factors. These results demonstrate that the spacers and RNP were located on the inner sides of the nano-pores with no significant damage in the hysteresis loop and verify the preservation of the porosity features of this nanocarrier during the modifying and loading processes $[80,86-88]$. This may lead to the conclusion that the large pore size of $\mathrm{AGu}_{\mathrm{PEG}} \mathrm{PE}_{150}-\mathrm{PMO}$ has remarkable capacity for loading and delivery, especially for high molecular weight proteins such as RNP [72, 8890]. Increasing the hydrothermal aging temperature and $\mathrm{H}_{2} \mathrm{SO}_{4}$-treating for removal of the organic template were resulted in PMOs with high total adsorption capacity and large pore sizes which is consistent with the previous results obtained for MSNs [58].

\section{In vitro evaluating study}

Biocompatibility is a major issue when the bioactive delivery nanosystems are developed for in vitro and in vivo applications. To illustrate the cytotoxicity of PMO based nanocarriers and RNP@AGu@PEG ${ }_{1500^{-}}$ PMO, MTT assay was performed on GFP-HT1080 cell as well as HT1080 and MCF10A cells as controls. As shown in Fig. 5a, after overnight exposure of different concentrations of $\mathrm{AGu} @ \mathrm{PEG}_{1500}-\mathrm{PMO}$ up to $200 \mu \mathrm{g}$. $\mathrm{mL}^{-1}$, a low level of cytotoxicity (cell viability $\geq 85 \%$ ) was observed which is consistent with the previous reports on cytotoxicity of $\mathrm{SiO}_{2}$ NPs cytotoxicity to HeLa, A375, and HepG2 cells [76, 91, 92]. Based on the result of the MTT assay, the AGu@PEGylated PMO nanocarrier at a concentration of $100 \mu \mathrm{g} \cdot \mathrm{mL}^{-1}$ was selected for RNP loading. The MTT assay of RNP@AGu@PEG ${ }_{1500}-\mathrm{PMO}$ showed no measurable toxic effects on the viability of GFP-HT1080 cell, HT1080, and on MCF10A cells even up to $240 \mathrm{nM}$ concentration of RNP (Fig. 5b), suggesting AGu@PEGylated as a potent nanocarrier for RNP based gene-editing.

To trace the uptake of $\mathrm{AGu@PEG}{ }_{1500}-\mathrm{PMO}$, it was loaded with sulforhodamine $B(\mathrm{SrB})$, a fluorescent hydrophilic dye $\left(\lambda_{e x}=565 \mathrm{~nm}, \lambda_{e m}=586 \mathrm{~nm}\right)$ [93]. SrB is generally a large-sized dye that is unable to penetrate through the cell wall. However, it can be uptaken by the cells via the encapsulation in the nanoporous materials.SrB@ $\mathrm{AGu@PEG} \mathrm{P}_{1500}-\mathrm{PMO}$ was prepared through the confinement of SrB into the large-pores of the AGu@PEG ${ }_{1500^{-}}$ PMO nanocarrier. Then, the uptake of SrB@AGu@ PEG1500-PMO was investigated by tracking of SrB for

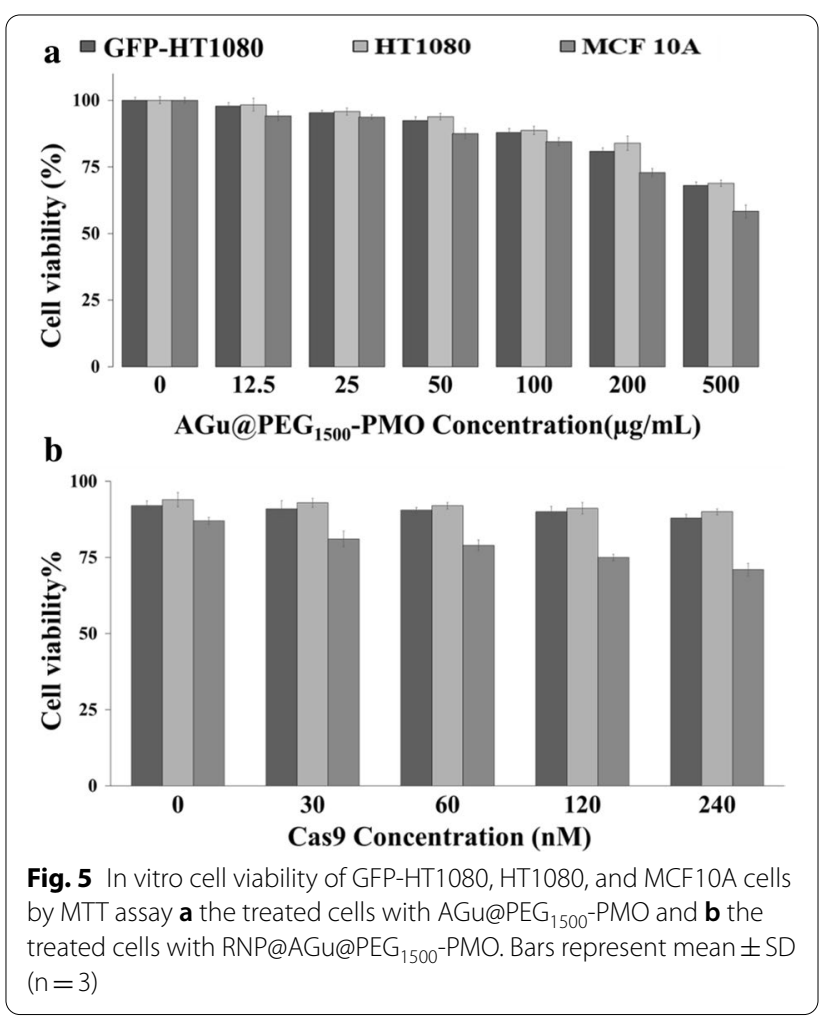


$6 \mathrm{~h}$ using confocal laser scanning microscopy (CLSM) (Fig. 6). The sulforhodamine B loaded $\mathrm{MCM}-\mathrm{NH}_{2}$ has been reported to illustrate the ability of $\mathrm{MCM}-\mathrm{NH}_{2}$ nanocarrier to intracellular deliver the cargoes [68]. After the incubation of GFP-HT1080 cells with SrB@AGu@ $\mathrm{PEG}_{1500}-\mathrm{PMO}, \mathrm{CLSM}$ images showed that the SrB@ AGu@PEG ${ }_{1500}-\mathrm{PMO}$ bound to the surface of the cell, entered into the cytosol, and was subsequently localized into the nuclei, as shown by the red fluorescence signal related toSrB@AGu@PEG ${ }_{1500}-\mathrm{PMO}$.

The observed results strongly highlighted the ability of AGu@PEG ${ }_{1500}$-PMO as a biocompatible nanovehicle to penetrate HT1080 cells and deliver the cargo with no notable change in cell morphology. According to these results, most of SrB@AGu@PEG ${ }_{1500}-\mathrm{PMO}$ entered the cells by endocytosis and released the cargo after degradation in the cells (Fig. 1). Due to the small size, MSNs can ease the uptake of different proteins into the cytosol thorough an endocytosis pathway and subsequent endosomal escape [94, 95]. It is stated that nanoporous silica nanomaterials facilitate the endosomal escape. It is proposed that the silica nanoparticles destabilize the endosomal membrane (the proton sponge effect) due to their $\mathrm{pH}$ buffering behaviors [94, 96]. In addition to the effective delivery capacity of $\mathrm{AGu} @ \mathrm{PEG}_{1500}-\mathrm{PMO}$ for the internalization of a gene therapeutic agent into the cells.

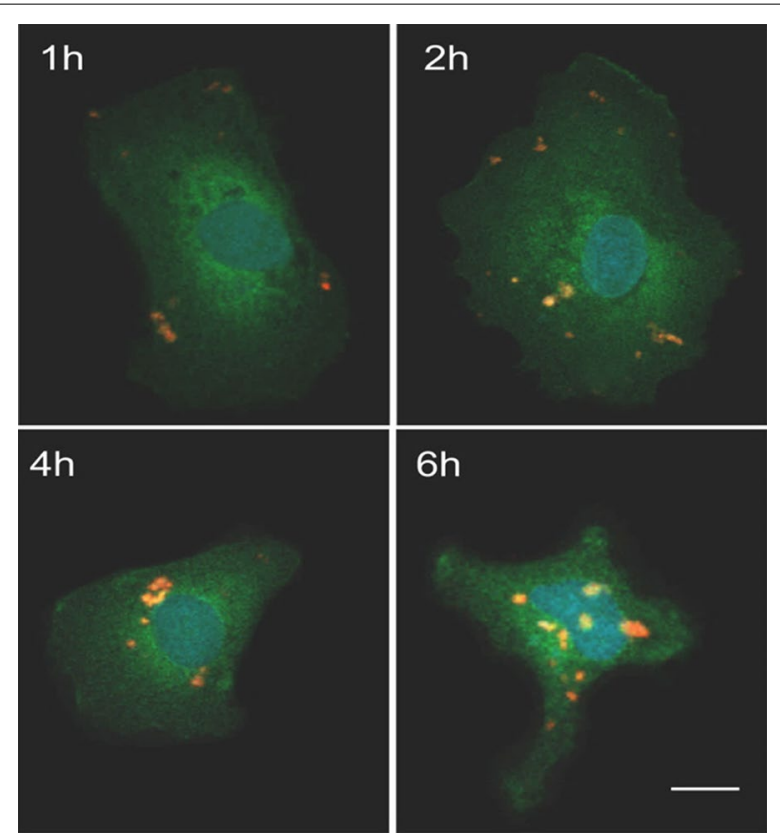

Fig. 6 Confocal fluorescence images of GFP-HT1080 cells displaying green fluorescence on their whole cell bodies, after incubation with SrB@AGu@PEG ${ }_{1500}-P M O$ for 1, 2, 4, and 6 h. Green: GFP, red: SrB@ AGu@PEG $1500-P M O$, and blue: nuclei stained with DAPI. Scale bar: $10 \mu \mathrm{m}$
Nanoporous silica nanomaterials possess stable framework with good biocompatibility and biodegradability to protect the biological molecules entrapped inside the nanopores from the unpleasant denaturation chemicals and conditions.

We expressed Cas9 protein in Escherichia coli (E. coli), purified, and complexed it with in vitro transcribed sgRNA targeting GFP gene (GFP-sgRNA). The functionality of RNP released from RNP@AGu@PEG ${ }_{1500}-\mathrm{PMO}$ was investigated by analyzing the cleavage of a PCR amplicon from the GFP genomic region. The results clearly demonstrated that after loading of RNP onto the AGu@PEG ${ }_{1500}-\mathrm{PMO}$, its endonuclease activity was maintained equivalent to that of its free version. Also, the free RNP ability to induce double-strand breaks (DSBs) in target DNA at physiological and acidic $\mathrm{pH}$ was preserved (Additional file 1: Figure S6). The gene-knockdown efficiency of the RNP@AGu@PEG ${ }_{1500}-\mathrm{PMO}$ as a Cas9sgRNA complex targeting GFP-gene was investigated in GFP-HT1080 cells as a model.

The GFP-gene knockdown was determined by the incubation of GFP-HT1080 cells with RNP@AGu@PEG $1_{1500^{-}}$ PMO (containing $120 \mathrm{nM}$ of Cas9). To investigate the efficiency of RNP@AGu@PEG ${ }_{1500}$-PMO to target the coding region of the gene and to generate Indels, early stop codon, and subsequently gene silencing, the fluorescence behaviors of the GFP-HT1080 cells were analyzed by the flow cytometry technique (Fig. 7). The flow cytometry results showed reduced GFP fluorescence (about 40\%) in $t$ the GFP-HT1080 cells treated with RNP@ AGu@PEG ${ }_{1500}-\mathrm{PMO}$ (Fig. 7a). The gene-knockdown has been also confirmed by sequencing the GFP gene in targeted cells. In contrast, the treated cells with free RNP and $A G u @ P E G_{1500}-P M O$ have shown negligible levels of GFP knockdown. These results clearly demonstrated the potential of $\mathrm{AGu} @ \mathrm{PEG}_{1500}-\mathrm{PMO} \mathrm{NPs}$ as a nanocarrier for intracellular RNP delivery to cells.

The GFP knockdown efficiency of RNP@AGu@ $\mathrm{PEG}_{1500}-\mathrm{PMO}$ is comparable with previous reports on gold nanoparticles with $30 \%$ editing efficiency [33], and DNA nanostructures-based RNP carriers with $36 \%$ editing efficiency [34]. However, DNA nanostructures often have complicated assembly process and can display poor chemical stability. Although the editing efficiencies of biopolymer-based nanoparticles have been reported up to $80 \%$, they often suffered from the issues of nontuneable size, non-programmable porosity, mostly burst release profiles, and highly interdependent features [75, $97,98]$. Furthermore, the toxicity of nanoparticles should be taken into account before considering them as efficient CRISPR delivery vehicles. In large doses, gold, some lipid-based NPs, and polymer NPs are potentially toxic in comparison to MSNs. Furthermore, the colloidal MSNs 


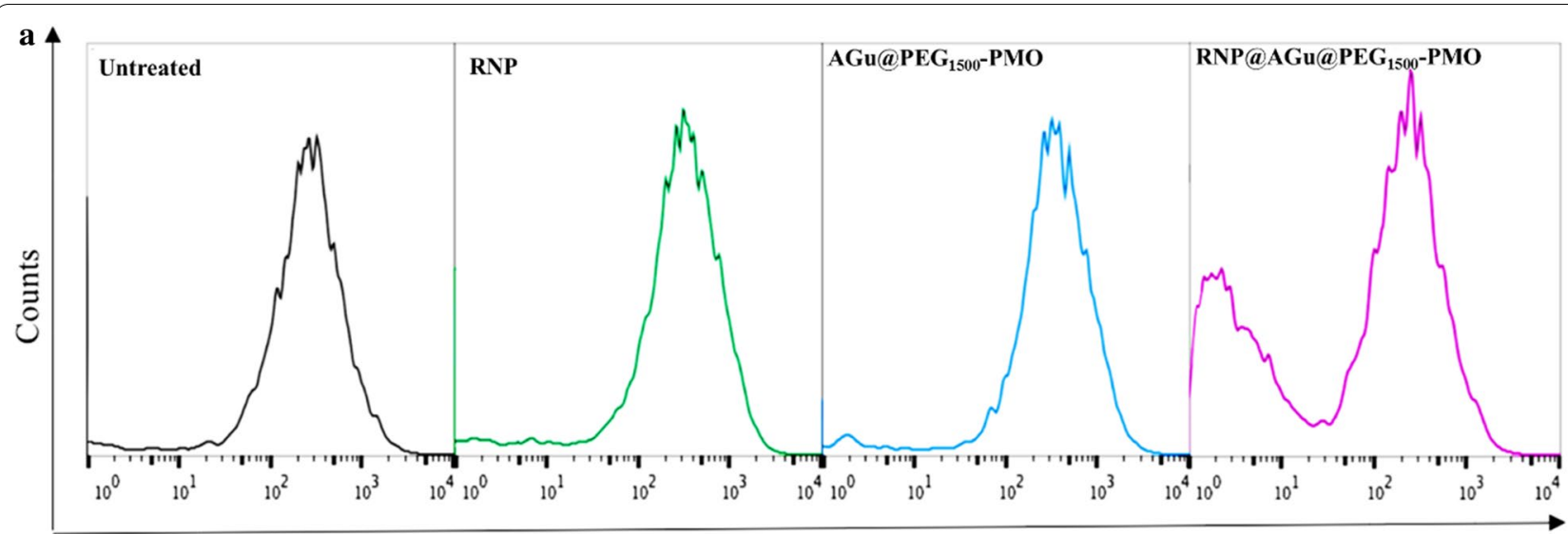

GFP Fluorescence

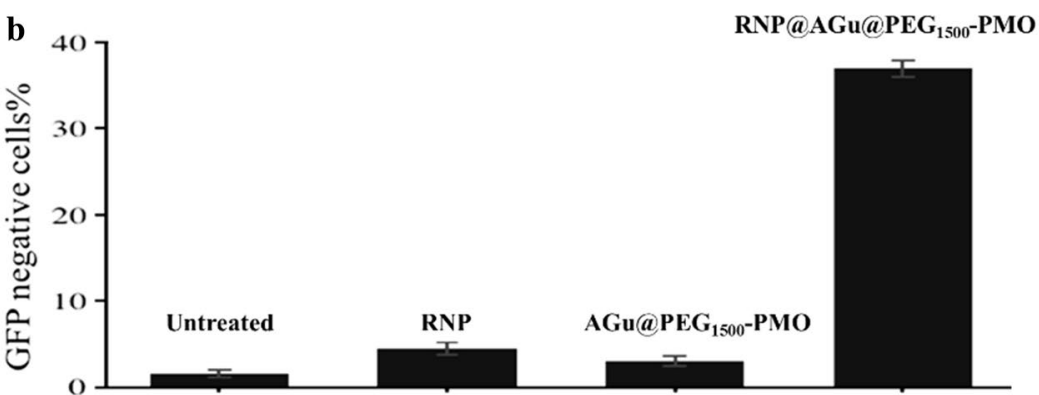

Fig. 7 Gene-editing using RNP@AGu@PEG 1500 -PMO, a flow-cytometry analysis of untreated GFP-HT1080 cells and the treated cell with free RNP, AGu@PEG 1500 -PMO, and RNP@AGu@PEG 1500 -PMO (RNP concentration is of 120 nM).X- and Y-axes indicate GFP fluorescence intensity and counts of cells, respectively; and $\mathbf{b}$ the quantification of Cas 9 activity based on flow-cytometry results. ${ }^{*} P<0.01$ as compared to the untreated. Bars represent mean $\pm S D(n=3)$

are biodegradable and generally recognized as safe by the FDA [99]. By comparison, PMOs demonstrate higher stability, greater surface area, and networks with uniformly and tuneable pores which pore diameter and surface chemistry can be manipulated widely to accommodate high loadings of varied cargos [100].

\section{Conclusions}

To our best knowledge, this is the first report on using large pore three-dimensional cubic Ia3d KIT-6 PMO as a biocompatible nanocarrier for intracellular delivery of RNP with a high gene-editing efficiency. Although MSNs and PMOs have similar silica networks, MSNs are created wholly of $\mathrm{SiO}_{2}$ framework while PMOsbased nanostructures are made of the bridged organic groups at the inner culture. This characteristic may provide remarkable advantages for PMOs including high loading/release efficiency, acceptable biocompatibility, and ease of functionalization. This makes (PMOs) promising candidate for various clinical applications.
There is a growing interest in improving the efficiency of Cas9-sgRNA system delivery to improve the stability of the Cas9 without compromising its efficacy. Herein, we have reported the application of large pore PMO-based nanocarrier with aminoguanidine pendent for the successful delivery of Cas9-sgRNA (RNP) complex. We introduced a novel bi-functionalized aminoguanidine-PEGylated periodic mesoporous organosilica KIT-6 PMO (RNP@AGu@PEG 1500 -PMO) which proved to be an ideal host for RNP due to the versatile surface properties. The facility of internal/external surface functionalization and tunable pore size give useful opportunities to optimize the condition for the RNP delivery. The ability of $\mathrm{AGu} @ \mathrm{PEG}_{1500}-\mathrm{PMO}$ for intracellular delivery and release of RNP is due to the proton sponge effect of aminoguanidine. The structure such AGu@PEG ${ }_{1500}-\mathrm{PMO}$ represents an example of the tuneable systems for delivery of Cas9-sgRNA complex that offers excellent potential for gene-editing based therapeutics and opens bright horizons to the stimuli-responsive nanocarriers as a great promise for 
nano-biomedicine in future. The development of novel smart and more efficient PMOs-based Cas9-sgRNA delivery systems for in-vitro and in-vivo CRISPR-based gene editing are worth to be further investigated.

\section{Supplementary Information}

The online version contains supplementary material available at https://doi. org/10.1186/s12951-021-00838-z.

Additional file 1: Table S1. The sequences of DNA oligos. Figure S1 SDS-PAGE gel electrophoresis (12\%) was applied to illustrate the efficiency of the loading, before and after adding AGu@PEG1500-PMO at different concentrations (including 30, 60, 120, and 240 nM) of Cas9. Cas9 concentrations were quantified with image j software. Figure S2. SDS-PAGE gel electrophoresis (12\%) of a) RNP released from RNP@AGU@PEG1500-PMO at $0,2,4,6,12$, and $24 \mathrm{~h}$ (lane 1-6), and known free RNP samples (lane a-d). Figure S3. SDS-PAGE (12\%) of purified Cas9. Figure S4. Agarose gel electrophoresis (1\%) of purified sgRNA. Figure S5. a) The fluorescence microscopy images with GFP filter, and b) bright field fluorescence microscopy images of the colony formed by expansion of single cell for 16,48 , and $120 \mathrm{~h}$. Scale bar: $200 \mu \mathrm{m}$. Figure S6. Agarose gel electrophoresis (1\%) of Cas 9 activity assay using GFP-PCR product from pLenti6.3-To-V5-DestGFP (645 bp) as substrate, a) released-RNP from RNP@AGu@PEG1500-PMO complex digest the PCR product at 7.5 (lane 1), b) free-RNP, and c) digest the PCR product at 7.5 and $5 \mathrm{pH}$ (lane 4 and lane 5 , respectively).

\section{Acknowledgements}

This study was partially supported by the Royan Institute.

\section{Authors' contributions}

PRS prepared the biomaterials, performed in vitro experiments, and helped in paper writing and editing. LM performed the conception and design of the study, synthesized and evaluated the nano-(bio)materials, and helped in paper writing and editing. JTB supervised the biological assays. HM and MHM advised in interpreting data. GHS performed the conception and design of the study, funding acquisition, and helped in paper writing and editing. All authors read and approved the final manuscript.

\section{Funding}

This paper was not financially supported.

\section{Availability of data and materials}

Not applicable.

\section{Declarations}

Ethics approval and consent to participate

Not applicable.

\section{Consent for publication}

Not applicable.

\section{Competing interests}

The authors declare that they have no competing interests.

\footnotetext{
Author details

${ }^{1}$ Department of Medical Genetics, School of Medicine, Tehran University of Medical Sciences, Tehran, Iran. ${ }^{2}$ Department of Nanotechnology, Agricultural Biotechnology Research Institute of Iran (ABRII), Agricultural Research Education and Extension Organization (AREEO), Karaj, Iran. ${ }^{3}$ Department of Systems and Synthetic Biology, Agricultural Biotechnology Research Institute of Iran (ABRII), Agricultural Research Education and Extension Organization (AREEO), Karaj, Iran. ${ }^{4}$ Department of Molecular Sciences, Macquarie University, Sydney, NSW, Australia.
}

Received: 29 September 2020 Accepted: 18 March 2021

Published online: 31 March 2021

\section{References}

1. Cho SW, Kim S, Kim JM, Kim JS. Targeted genome engineering in human cells with the Cas9 RNA-guided endonuclease. Nat Biotechnol. 2013;31:230-2. https://doi.org/10.1038/nbt.2507.

2. Adli M. The CRISPR tool kit for genome editing and beyond. Nat Commun. 2018;9:1-13. https://doi.org/10.1038/s41467-018-04252-2.

3. Barrangou R, Doudna JA. Applications of CRISPR technologies in research and beyond. Nat Biotechnol. 2016;34:933-41. https://doi. org/10.1038/nbt.3659.

4. Xia AL, He QF, Wang JC, et al. Applications and advances of CRISPRCas9 in cancer immunotherapy. J Med Genet. 2019;56:4-9. https:// doi.org/10.1136/jmedgenet-2018-105422.

5. Cyranoski D. CRISPR gene-editing tested in a person for the first time. Nat News. 2016;539:479-479. https://doi.org/10.1038/nature.2016. 20988.

6. Moreno AM, Fu X, Zhu J, et al. In situ gene therapy via AAV-CRISPRCas9-mediated targeted gene regulation. Mol Ther. 2018;26:1818-27. https://doi.org/10.1016/j.ymthe.2018.04.017.

7. De Ravin SS, Li L, Wu X, et al. CRISPR-Cas9 gene repair of hematopoietic stem cells from patients with X-linked chronic granulomatous disease. Sci Transl Med. 2017;9:eaah3480. https://doi.org/10.1126/ scitransImed.aah3480.

8. Qi C, Li D, Jiang X, et al. Inducing CCR5D32/D32 homozygotes in the humanjurkat CD4+ cell line and primary CD4+ Cells by CRISPR-Cas9 genome-editing technology. Mol Ther Nucleic Acids. 2018;12:267-74. https://doi.org/10.1016/j.omtn.2018.05.012.

9. Xiao Q, Guo D, Chen S. Application of CRISPR/Cas9-based gene editing in HIV-1/AIDS therapy. Front Cell Infect Microbiol. 2019;9:1-15. https:// doi.org/10.3389/fcimb.2019.00069.

10. Stadtmauer EA, Fraietta JA, Davis MM, et al. CRISPR-engineered T cells in patients with refractory cancer. Science. 2020;367:eaba7365. https://doi. org/10.1126/science.aba7365.

11. Zhan T, Rindtorff N, Betge J, Ebert MP, Boutros M. CRISPR/Cas9 for cancer research and therapy. Semin Cancer Biol. 2019;55:106-19. https:// doi.org/10.1016/j.semcancer.2018.04.001.

12. Kang JG, Park JS, Ko J, Kim YS. Regulation of gene expression by altered promoter methylation using a CRISPR/Cas9-mediated epigenetic editing system. Sci Rep. 2019;9:11960. https://doi.org/10.1038/ s41598-019-48130-3.

13. Katayama S, Moriguchi T, Ohtsu N, Kondo T. A powerful CRISPR/Cas9based method for targeted transcriptional activation. Angew Chemie. 2016;128:6562-6. https://doi.org/10.1002/anie.201601708.

14. Kiani S, Chavez A, Tuttle $M$, et al. Cas 9 gRNA engineering for genome editing, activation and repression. Nat Methods. 2015;12:1051-4. https://doi.org/10.1038/nmeth.3580.

15. Chen B, Gilbert LA, Cimini BA, et al. Dynamic imaging of genomic loci in living human cells by an optimized CRISPR/Cas system. Cell. 2013;155:1479-91. https://doi.org/10.1016/j.cell.2013.12.001.

16. Wang $H$, Nakamura $M$, Abbott TR, et al. CRISPR-mediated live imaging of genome editing and transcription. Science. 2019;365:1301-5. https:// doi.org/10.1126/science.aax7852.

17. Ran FA, Hsu PD, Wright J, Agarwala V, Scott DA, Zhang F. Genome engineering using the CRISPR-Cas9 system. Nat Protoc. 2013;8:2281. https:// doi.org/10.1038/nprot.2013.143.

18. Niu Y, Shen B, Cui Y, et al. Generation of gene-modified cynomolgus monkey via Cas9/RNA-mediated gene targeting in one-cell embryos. Cell. 2014;156:836-43. https://doi.org/10.1038/nprot.2013.143.

19. Zuris JA, Thompson DB, Shu Y, et al. Cationic lipid-mediated delivery of proteins enables efficient protein-based genome editing in vitro and in vivo. Nat Biotechnol. 2015;33:73-80. https://doi.org/10.1038/nbt. 3081.

20. Chew WL, Tabebordbar M, Cheng JK, et al. A multifunctional AAVCRISPR-Cas9 and its host response. Nat Methods. 2016;13:868-74. https://doi.org/10.1038/nmeth.3993.

21. Kim S, Kim D, Cho SW, Kim J, Kim JS. Highly efficient RNA-guided genome editing in human cells via delivery of purified Cas9 
ribonucleoproteins. Genome Res. 2014;24:1012-9. https://doi.org/10. 1101/gr.171322.113.

22. Schumann K, Lin S, Boyer E, et al. Generation of knock-in primary human T cells using Cas9 ribonucleoproteins. Proc Natl Acad Sci USA. 2015;112:10437-42. https://doi.org/10.1073/pnas.1512503112.

23. Han X, Liu Z, Jo MC, et al. CRISPR-Cas9 delivery to hard-to-transfect cells via membrane deformation. Sci Adv. 2015;1:e1500454. https://doi.org/ $10.1126 /$ sciadv. 1500454

24. Xu L, Park KH, Zhao L, et al. CRISPR-mediated Genome Editing Restores Dystrophin Expression and Function in mdx Mice. Mol Ther. 2016;24:564-9. https://doi.org/10.1038/mt.2015.192.

25. Petris G, Casini A, Montagna C, et al. Hit and go CAS9 delivered through a lentiviral based self-limiting circuit. Nat Commun. 2017;8:15334. https://doi.org/10.1038/ncomms15334.

26. Cheng R, Peng J, Yan Y, et al. Efficient gene editing in adult mouse livers via adenoviral delivery of CRISPR/Cas9. FEBS letts. 2014;588:3954-8. https://doi.org/10.1016/j.febslet.2014.09.008.

27. Deng H, Huang W, Zhang Z. Nanotechnology based CRISPR/Cas9 system delivery for genome editing: progress and prospect. Nano Res. 2019:12:2437-50. https://doi.org/10.1007/s12274-019-2465-x.

28. Staahl BT, Benekareddy M, Coulon-Bainier C, et al. Efficient genome editing in the mouse brain by local delivery of engineered Cas 9 ribonucleoprotein complexes. Nat Biotechnol. 2017;35:431-4. https://doi.org/ $10.1038 /$ nbt.3806

29. Ramakrishna S, Kwaku Dad AB, Beloor J, Gopalappa R, Lee SK, Kim H. Gene disruption by cell-penetrating peptide-mediated delivery of Cas9 protein and guide RNA. Genome Res. 2014;24:1020-7. https://doi.org/ 10.1101/gr.171264.113.

30. Yin $\mathrm{H}$, Song CQ, Dorkin JR, et al. Therapeutic genome editing by combined viral and non-viral delivery of CRISPR system components in vivo. Nat Biotechnol. 2016;34:328-33. https://doi.org/10.1038/nbt.3471.

31. Wang M, Zuris JA, Meng F, et al. Efficient delivery of genome-editing proteins using bioreducible lipid nanoparticles. Proc Natl Acad Sci USA. 2016;113:2868-73. https://doi.org/10.1073/pnas.1520244113.

32. Yue H, Zhou X, Cheng M, Xing D. Graphene oxide-mediated Cas9/ sgRNA delivery for efficient genome editing. Nanoscale. 2018;10:106371. https://doi.org/10.1039/C7NR07999K.

33. Mout R, Ray M, Tonga GY, Lee YM, Tay T, Sasaki K, Rotello VM. Direct cytosolic delivery of CRISPR/Cas9-ribonucleoprotein for efficient gene editing. ACS Nano. 2017;11:2452-8. https://doi.org/10.1021/acsnano. $6 \mathrm{~b} 07600$.

34. Sun W, Ji W, Hall JM. Self-assembled DNA nanoclews for the efficient delivery of CRISPR-Cas9 for genome editing. Angew Chem Int Ed Engl. 2015:54:12029-33. https://doi.org/10.1002/anie.201506030.

35. Alsaiari SK, Patil S, Alyami M, et al. Endosomal escape and delivery of CRISPR/Cas9 genome editing machinery enabled by nanoscale zeolitic imidazolate framework. J Am Chem Soc. 2018;140:143-6. https://doi. org/10.1021/jacs.7b11754

36. Chen G, Abdeen AA, Wang Y, et al. A biodegradable nanocapsule delivers a Cas9 ribonucleoprotein complex for in vivo genome editing. Nat Nanotechnol. 2019;14:974-80. https://doi.org/10.1038/ s41565-019-0539-2.

37. Jain PK, Lo JH, Rananaware S, et al. Non-viral delivery of CRISPR/Cas9 complex using CRISPR-GPS nanocomplexes. Nanoscale. 2019;11:2131723. https://doi.org/10.1039/c9nr01786k.

38. Zhu H, Zhang L, Tong S, Lee CM, Deshmukh H, Bao G. Spatial control of in vivo CRISPR-Cas9 genome editing via nanomagnets. Nat Biomed Eng. 2019;3:126-36. https://doi.org/10.1038/s41551-018-0318-7.

39. Abdelhamid HN, Dowaidar M, Hälllbrink M, Langel Ü. Gene delivery using cell penetrating peptides-zeolitic imidazolate frameworks. Microporous Mesoporous Mater. 2020;14:110173. https://doi.org/10 1016/j.micromeso.2020.110173.

40. Abdelhamid HN, Dowaidar M, Langel Ü. Carbonized chitosan encapsulated hierarchical porous zeolitic imidazolate frameworks nanoparticles for gene delivery. Microporous Mesoporous Mater. 2020;10:110200. https://doi.org/10.1016/.micromeso.2020.110200.

41. Dowaidar M, Abdelhamid HN, Hällbrink M, Freimann K, Kurrikoff K, Zou X, Langel Ü. Magnetic nanoparticle assisted self-assembly of cell penetrating peptides-oligonucleotides complexes for gene delivery. Sci Rep. 2017:22(7):1-11. https://doi.org/10.1038/s41598-017-09803-z.
42. Dowaidar M, Abdelhamid HN, Hällbrink M, Zou X. Langel Ü (2017) Graphene oxide nanosheets in complex with cell penetrating peptides for oligonucleotides delivery. Biochimica et Biophysica Acta (BBA) General Subjects. 1861;9:2334-41. https://doi.org/10.1016/j.bbagen.2017.07. 002.

43. Xu X, Koivisto O, Liu C, et al. Effective delivery of the CRISPR/Cas9 system enabled by functionalized mesoporous silica nanoparticles for GFP-tagged paxillin knock-in. Adv Therap. 2020. https://doi.org/10. 1002/adtp.202000072.

44. Oh JY, Kim HS, Palanikumar L, et al. Cloaking nanoparticles with protein corona shield for targeted drug delivery. Nat Commun. 2018;9:4548. https://doi.org/10.1038/s41467-018-06979-4.

45. Liu B, Ejaz W, Gong S, et al. Engineered interactions with mesoporous silica facilitate intracellular delivery of proteins and gene editing. Nano Lett. 2020;20:4014-21. https://doi.org/10.1021/acs.nanolett.0c01387.

46. Baliś A, Wolski K, Zapotoczny S. Thermoresponsive polymer gating system on mesoporous shells of silica particles serving as smart nanocontainers. Polymers. 2020;12:888. https://doi.org/10.3390/polym12040 888.

47. Baliś A, Zapotoczny S. Tailored synthesis of core-shell mesoporous silica particles-Optimization of dye sorption properties. Nanomaterials. 2018;8:230. https://doi.org/10.3390/nano8040230.

48. Hong $X$, Zhong $X$, Du G, Hou Y, Zhang Y, Zhang Z, Gong T, Zhang L, Sun $X$. The pore size of mesoporous silica nanoparticles regulates their antigen delivery efficiency. Sci Adv. 2020;6:eaaz4462. https://doi.org/10. 1126/sciadv.aaz4462.

49. Ha CS, Park SS. Periodic mesoporous organosilicas preparation properties and applications. Singapore: Springer; 2019. https://doi.org/10. 1007/978-981-13-2959-3.

50. VanDer-Voort P, Esquivel D, De Canck E, Goethals F, Van Driesscheb I, Romero-Salgueroc FJ. Periodic Mesoporous Organosilicas: from simple to complex bridges; a comprehensive overview of functions, morphologies and applications. Chem Soc Rev. 2013;42:3913-55. https://doi.org/10.1039/C5NR05649G.

51. Croissant JG, Cattoën X, Man MWC, Durand JO, Khashab NM. Syntheses and applications of periodic mesoporous organosilica nanoparticles. Nanoscale. 2015;7:20318-34. https://doi.org/10.1039/C5NRO 5649G.

52. Zhang W-H, Daly B, O'Callaghan J, et al. Large pore methylenebridged periodic mesoporous organosilicas: synthesis, bifunctionalization and their use as nanotemplates. Chem Mater. 2005;17:640715. https://doi.org/10.1021/cm050502h.

53. Bao XY, Li X, Zhao XS. Synthesis of large-pore methylene-bridged periodic mesoporous organosilicas and its implications. J Phys Chem B. 2006;110:2656-61. https://doi.org/10.1021/jp0561120.

54. Park J, Fong PM, Lu J, Russell KS, Booth CJ, Fahmy WM. PEGylated PLGA nanoparticles for the improved delivery of doxorubicin. Nanomedicine Nanotechnol Biol Med. 2009;5:410-8. https://doi.org/10. 1016/j.nano.2009.02.002.

55. Faure AC, Dufort $\mathrm{S}$, Josserand V, et al. Control of the in vivo biodistribution of hybrid nanoparticles with different poly(ethylene glycol) coatings. Small. 2009;5:2565-75. https://doi.org/10.1002/smll.20090 0563

56. Ma'mani L, Nikzad S, Manjili HK, et al. Curcumin-loaded guanidine functionalized PEGylated I3ad mesoporous silica nanoparticles KIT-6: practical strategy for the breast cancer therapy. Eur J Med Chem. 2014;83:646-54. https://doi.org/10.1016/j.ejmech.2014.06.069.

57. Guo W, Kleitz F, Cho K, Ryoo R. Large pore phenylene-bridged mesoporous organosilica with bicontinuous cubic la3 [combining macron] d (KIT-6) mesostructure. J Mater Chem. 2010;20:8257-65. https://doi.org/10.1039/c0jm01518k

58. Guillet-Nicolas R, Ahmad R, Cychosz KA, Kleitz F, Thommes M. Insights into the pore structure of KIT- 6 and SBA-15 ordered mesoporous silica-recent advances by combining physical adsorption with mercury porosimetry. New J Chem. 2016;40:4351-60. https://doi.org/10.1039/ c5nj03466c.

59. Zhuang X, Qian X, LV J, Wan Y. An alternative method to remove PEOPPO-PEO template in organic-inorganic mesoporous nanocomposites by sulfuric acid extraction. Appl Surf Sci. 2010;256:5343-8. https://doi. org/10.1016/j.apsusc.2009.12.074 
60. Karmakar B, Nandi R. A green route towards substituted 2-amino-4 $\mathrm{H}$-chromenes catalyzed by an organobase (TBD) functionalized mesoporous silica nanoparticle without heating. Res Chem Intermed. 2016;14:1-12. https://doi.org/10.1007/s11164-016-2755-9.

61. Gurung M, Adhikari BB, Morisada S, Kawakita H, Ohto K, Inoue K, Alam S. N-aminoguanidine modified persimmon tannin: a new sustainable material for selective adsorption, preconcentration and recovery of precious metals from acidic chloride solution. Biores Technol. 2013;129:108-17. https://doi.org/10.1016/j.biortech.2012.11.012.

62. Karvelis T, Gasiunas G, Young J, et al. Rapid characterization of CRISPRCas9 protospacer adjacent motif sequence elements. Genome Biol. 2015;16:253-66. https://doi.org/10.1186/s13059-015-0818-7.

63. Knight Ml, Chambers PJ. Problems associated with determining protein concentration: a comparison of techniques for protein estimations. Mol Biotechnol. 2003;23:19-28. https://doi.org/10.1385/MB:23:1:19.

64. Schneider CA, Rasband WS, Eliceiri KW. NIH Image to ImageJ: 25 years of image analysis. Nat Methods. 2012;9:671-5. https://doi.org/10.1038/ nmeth.2089.

65. Wai-Hoe L, Wing-Seng L, Ismail Z, Lay-Harn G. SDS-PAGE-based quantitative assay for screening of kidney stone disease. Biological Proced Online. 2009;11(1):145-60. https://doi.org/10.1007/s12575-009-9007-y.

66. Chin JX, Chung BKS, Lee DY. Codon Optimization OnLine (COOL): a web-based multi-objective optimization platform for synthetic gene design. Bioinformatics. 2014;30:2210-2. https://doi.org/10.1093/bioin formatics/btu192.

67. Denning W, Das S, Guo S, Xu J, Kappes JC, Hel Z. Optimization of the transductional efficiency of lentiviral vectors: effect of sera and polycations. Mol Biotechnol. 2013;53:308-14. https://doi.org/10.1007/ s12033-012-9528-5.

68. Nguyen CTH, Webb Rl, Lambert LK, et al. Bifunctional succinylated $\varepsilon$-polylysine-coated mesoporous silica nanoparticles for $\mathrm{pH}$-responsive and intracellular drug delivery targeting the colon. ACS Appl Mater Interfaces. 2017;9:9470-83. https://doi.org/10.1021/acsami.7b00411.

69. Yang P, Gai S, Lin J. Functionalized mesoporous silica materials for controlled drug delivery. Chem Soc Rev. 2012;41(9):3679-98. https:// doi.org/10.1039/c2cs15308d.

70. Lin CH, Kumar Kankala R, Busa P, Lee CH. Hydrophobicity-tuned periodic mesoporous organo-silica nanoparticles for photodynamic therapy. Int J Mol Sci. 2020;21(7):2586. https://doi.org/10.3390/ijms2 1072586.

71. Ito T, Sun L, Bevan MA, Crooks RM. Comparison of nanoparticle size and electrophoretic mobility measurements using a carbon-nanotube-based coulter counter, dynamic light scattering, transmission electron microscopy, and phase analysis light scattering. Langmuir. 2004;20(16):6940-5. https://doi.org/10.1021/la049524t.

72. Zhou B, Li CY, Qi N, Jiang M, Wang B, Chen ZQ. Pore structure of mesoporous silica (KIT-6) synthesized at different temperatures using positron as a nondestructive probe. Appl Surf Sci. 2018;450:31-7. https://doi.org/10.1016/j.apsusc.2018.03.223.

73. Falahati M, Ma'mani L, Saboury AA, Shafiee A, Foroumadi A, Badiei A. Aminopropyl-functionalized cubic la3d mesoporous silica nanoparticle as an efficient support for immobilization of superoxide dismutase. Biochim Biophys Acta Proteins Proteomics. 2011;1814:1195-202. https:// doi.org/10.1016/j.bbapap.2011.04.005.

74. Timm J, Bloesser A, Zhang S, Scheu C, Marschall R. Stabilization of nanosized MgFe2O4 nanoparticles in phenylene-bridged KIT-6-type ordered mesoporous organosilica (PMO). Microporous Mesoporous Mater. 2020;293:109783. https://doi.org/10.1016/j.micromeso.2019.109783.

75. Zhen S, Li X. Liposomal delivery of CRISPR/Cas9. Cancer Gene Ther. 2019;27:515-27. https://doi.org/10.1038/s41417-019-0141-7.

76. Zeng Z, Chen M, Pei Y, Shahabadi SI, Che B, Wang P, Lu X. Ultralight and flexible polyurethane/silver nanowire nanocomposites with unidirectional pores for highly effective electromagnetic shielding. ACS Appl Mater Interfaces. 2017;9(37):32211-9. https://doi.org/10.1021/acsami. 6b11324.

77. Vallet-Regí M. Ordered mesoporous materials in the context of drug delivery systems and bone tissue engineering. Chem Eur J. 2006;12(23):5934-43. https://doi.org/10.1002/chem.200600226.

78. Xu C, Lei C, Yu C. Mesoporous silica nanoparticles for protein protection and delivery. Front Chem. 2019;7:290. https://doi.org/10.3389/fchem. 2019.00290 .
79. Cho EB, Kim D, Jaroniec M. Bifunctional periodic mesoporous organosilicas with thiophene and isocyanurate bridging groups. Langmuir. 2009;25(22):13258-63. https://doi.org/10.1021/la902089c.

80. Bathen ME, Linder J. Spin Seebeck effect and thermoelectric phenomena in superconducting hybrids with magnetic textures or spin-orbit coupling. Sci Rep. 2017;7:41409. https://doi.org/10.1038/srep45055.

81. Mady MM, Mohammed WA, El-Guendy NM, Elsayed AA. Interaction of DNA and polyethylenimine: Fourier-transform infrared (FTIR) and differential scanning calorimetry (DSC) studies. Int J Phys Sci. 2011;6(32):7328-34. https://doi.org/10.5897/JJPS11.1005.

82. Liu L, Zhang HT, Shen B, He W, Liu Y, Lu GY, Zhu JJ. pH-induced fabrication of DNA/chitosan/a-ZrP nanocomposite and DNA release. Nanotechnology. 2010;21(10):105102. https://doi.org/10.1088/0957-4484/ 21/10/105102.

83. Watson SM, Mohamed HD, Horrocks BR, Houlton A. Electrically conductive magnetic nanowires using an electrochemical DNA-templating route. Nanoscale. 2013;5(12):5349-59. https://doi.org/10.1039/C3NRO 0716B.

84. Alallam B, Altahhan S, Taher M, Mohd Nasir MH, Doolaanea AA. Electrosprayed alginate nanoparticles as CRISPR plasmid DNA delivery carrier: preparation, optimization, and characterization. Pharmaceuticals. 2020;13(8):158. https://doi.org/10.3390/ph13080158.

85. Fatieiev Y, Croissant JG, Julfakyan K, Deng L, Anjum DH, Gurinov A, Khashab NM. Enzymatically degradable hybrid organic-inorganic bridged silsesquioxane nanoparticles for in vitro imaging. Nanoscale. 2015;7(37):15046-50. https://doi.org/10.1039/C5NR03065J.

86. Xu C, Yu M, Noonan O, Zhang J, Song H, Zhang H, Lei C, Niu Y, Huang $X$, Yang $Y, Y u C$. Core-cone structured monodispersed mesoporous silica nanoparticles with ultra-large cavity for protein delivery. Small. 2015;11(44):5949-55. https://doi.org/10.1002/smll.201501449.

87. Guan B, Cui Y, Ren Z, Qiao ZA, Wang L, Liu Y, Huo Q. Highly ordered periodic mesoporous organosilica nanoparticles with controllable pore structures. Nanoscale. 2012;4(20):6588-96. https://doi.org/10.1039/ c2nr31662e.

88. Meka AK, Abbaraju PL, Song H, Xu C, Zhang J, Zhang H, Yu M, Yu C. A vesicle supra-assembly approach to synthesize amine-functionalized hollow dendritic mesoporous silica nanospheres for protein delivery. Small. 2016;12(37):5169-77. https://doi.org/10.1002/smll.201602052.

89. Calin N, Galarneau A, Cacciaguerra T, Denoyel R, Fajula F. Epoxyfunctionalized large-pore SBA-15 and KIT-6 as affinity chromatography supports. C R Chim. 2010;13(1-2):199-206. https://doi.org/10.1016/j. crci.2009.04.001.

90. Kleitz F, Choi SH, Ryoo R. Cubic la3d large mesoporous silica: synthesis and replication to platinum nanowires, carbon nanorods and carbon nanotubes. Chem Commun. 2003;17:2136-7. https://doi.org/10.1039/ B306504A.

91. Lin W, Huang YW, Zhou XD, Ma Y. In vitro toxicity of silica nanoparticles in human lung cancer cells. Toxicol Appl Pharmacol. 2006;217:252-9. https://doi.org/10.1016/j.taap.2006.10.004.

92. Huang $X$, Teng $X$, Chen D, Tang F, He J. The effect of the shape of mesoporous silica nanoparticles on cellular uptake and cell function. Biomaterials. 2010;31:438-48. https://doi.org/10.1016/j.biomaterials. 2009.09.060.

93. Stachowiak JC, Richmond DL, Li TH, Liu AP, Parekh SH, Fletcher DA. Unilamellar vesicle formation and encapsulation by microfluidic jetting. Proc Natl Acad Sci. 2008;105(12):4697-702. https://doi.org/10.1073/ pnas.0710875105.

94. Slowing II, Vivero-Escoto $\mathrm{L}$, Wu CW, Lin VSY. Mesoporous silica nanoparticles as controlled release drug delivery and gene transfection carriers. Adv Drug Delivery Rev. 2008;60(11):1278-88. https://doi.org/10. 1016/j.addr.2008.03.012

95. Martens TF, Remaut K, Demeester J, De Smedt SC, Braeckmans K. Intracellular delivery of nanomaterials: how to catch endosomal escape in the act. Nano Today. 2014;9(3):344-64. https://doi.org/10.1016/j.nantod. 2014.04.011.

96. Huang DM, Hung Y, Ko BS, Hsu SC, Chen WH, Chien CL, Tsai CP, Kuo CT, Kang JC, Yang CS, Mou CY. Highly efficient cellular labeling of mesoporous nanoparticles in human mesenchymal stem cells: implication for stem cell tracking. FASEB J. 2005;19(14):2014-6. https://doi.org/ 10.1096/fi.05-4288fie. 
97. Jo A, Ringel-Scaia VM, McDaniel DK, et al. Fabrication and characterization of PLGA nanoparticles encapsulating large CRISPR-Cas9 plasmid. J Nanobiotechnology. 2020;18:1-14. https://doi.org/10.1186/ s12951-019-0564-1.

98. Kang $X$, He W, Huang $Y$, et al. Introducing precise genetic modifications into human 3PN embryos by CRISPR/Cas-mediated genome editing. J Assist Reprod Genet. 2016;33:581-8. https://doi.org/10.1007/ s10815-016-0710-8.

99. Watermann A, Brieger J. Mesoporous silica nanoparticles as drug delivery vehicles in cancer. Nanomaterials. 2017;7:189-206. https://doi.org/ 10.3390/nano7070189.
100. Zhou Y, Quan G, Wu Q, et al. Mesoporous silica nanoparticles for drug and gene delivery. Acta Pharm Sin B. 2018;8:165-77. https://doi.org/10. 1016/j.apsb.2018.01.007.

\section{Publisher's Note}

Springer Nature remains neutral with regard to jurisdictional claims in published maps and institutional affiliations.
Ready to submit your research? Choose BMC and benefit from:

- fast, convenient online submission

- thorough peer review by experienced researchers in your field

- rapid publication on acceptance

- support for research data, including large and complex data types

- gold Open Access which fosters wider collaboration and increased citations

- maximum visibility for your research: over $100 \mathrm{M}$ website views per year

At BMC, research is always in progress.

Learn more biomedcentral.com/submissions 